\title{
Growth factors in multiple myeloma: a comprehensive analysis of their expression in tumor cells and bone marrow environment using Affymetrix microarrays
}

\author{
Karène Mahtouk1, Jérôme Moreaux 1,2, Dirk Hose3,4, Thierry Rème1,2, Tobias Meißner ${ }^{3}$, Michel Jourdan1, \\ Jean François Rossi1,2,5, Steven T Pals6, Hartmut Goldschmidt3,4 and Bernard Klein*1,2,5
}

\begin{abstract}
Background: Multiple myeloma (MM) is characterized by a strong dependence of the tumor cells on their microenvironment, which produces growth factors supporting survival and proliferation of myeloma cells (MMC). In the past few years, many myeloma growth factors (MGF) have been described in the literature. However, their relative importance and the nature of the cells producing MGF remain unidentified for many of them.

Methods: We have analysed the expression of 51 MGF and 36 MGF receptors (MGFR) using Affymetrix microarrays throughout normal plasma cell differentiation, in MMC and in cells from the bone marrow (BM) microenvironment (CD14, CD3, polymorphonuclear neutrophils, stromal cells and osteoclasts).
\end{abstract}

Results: 4/51 MGF and 9/36 MGF-receptors genes were significantly overexpressed in plasmablasts (PPC) and BM plasma cell (BMPC) compared to B cells whereas 11 MGF and 11 MGFR genes were overexpressed in BMPC compared to PPC. 3 MGF genes (AREG, NRG3, Wnt5A) and none of the receptors were significantly overexpressed in MMC versus BMPC. Furthermore, 3/51 MGF genes were overexpressed in MMC compared to the the BM microenvironment whereas 22/51 MGF genes were overexpressed in one environment subpopulation compared to MMC.

Conclusions: Two major messages arise from this analysis 1) The majority of MGF genes is expressed by the bone marrow environment. 2) Several MGF and their receptors are overexpressed throughout normal plasma cell differentiation. This study provides an extensive and comparative analysis of MGF expression in plasma cell differentiation and in MM and gives new insights in the understanding of intercellular communication signals in MM.

\section{Background}

Multiple myeloma (MM) is a B cell neoplasia that affects 15000 new patients per year in Europe and 15000 in the United States. It is still an incurable disease with an average 5-year survival after high dose chemotherapy and autologous stem cells transplantation [1]. MM is characterized by the accumulation of a clone of malignant plasma cells in the bone marrow (BM). Hallmarks of MM are the presence of genetic abnormalities [2] and the dependence of tumor cells on their environment through cell communication signals [3]. Since the identification of

\footnotetext{
* Correspondence: bernard.klein@inserm.fr

1 INSERM, U847, Montpellier, F-34197 France

Full list of author information is available at the end of the article
}

IL-6 [4-6] and IGF-1 [7] as major myeloma growth factor (MGF) in 1988 and 1996, respectively, the identification of new autocrine and/or paracrine MGF has been constantly increasing, making it difficult to understand intercellular communication signals in MM (see $[3,8]$ for review and Table A1A). This is however a major question, in particular with the aim to design novel targeted therapies for MM.

In this study, we have used U133P 2.0 Affymetrix microarrays to analyse the expression of a large panel of MGF in BM aspirates from MM patients, in purified cell subpopulations present in the BM of those patients, i.e CD138+ multiple myeloma cells (MMC), CD14+ monocytes, CD15+ polymorphonuclear neutrophils (PMN) 
Table 1: List of growth factors investigated in the study.

\begin{tabular}{|c|c|c|}
\hline \multicolumn{3}{|c|}{ A. Growth factors that have been reported to be involved in myeloma biology. } \\
\hline Growth factor & probe set & References $(*)$ \\
\hline - Insulin-like growth factor-1 (IGF-1) & 209541_at & {$[7,35-39]$} \\
\hline - Hepatocyte growth factor (HGF) & 210997_at & {$[41-46]$} \\
\hline $\begin{array}{l}\text { - Macrophage inflammatory protein } 1 \text { a } \\
\text { (MIP1a/CCL3) }\end{array}$ & 205114_s_at & {$[53-56]$} \\
\hline - Growth/differentiation factor 15 (GDF15) & 221577_x_at & {$[24]$} \\
\hline - pleiotrophin (PTN) & 209466_x_at & {$[57,58]$} \\
\hline - Brain derived neurotrophic factor (BDNF) & 206382_s_at & [59] \\
\hline \multicolumn{3}{|l|}{ IL-6 family cytokines } \\
\hline - Interleukin 6 (IL-6) & 205207_at & {$[4,5,19,33-35,60-68]$} \\
\hline - Ciliary neurotrophic factor (CNTF) & NA & [69] \\
\hline - oncostatin M (OSM) & 230170_at & " " \\
\hline - Leukemia inhibitory factor (LIF) & 205266_at & " " \\
\hline - Interleukin 11 (IL-11) & NA & " " \\
\hline $\begin{array}{l}\text { - cardiotrophin-like cytokine factor } 1 \\
\text { (CLCF1) }\end{array}$ & 219500_at & {$[70]$} \\
\hline \multicolumn{3}{|l|}{ Other interleukins } \\
\hline - interleukin $1 \beta(\mathrm{IL}-1 \beta)$ & 39402_at & {$[18]$} \\
\hline - interleukin 10 (IL-10) & 207433_at & {$[71,72]$} \\
\hline - interleukin 15 (IL-15) & 205992_s_at & {$[73]$} \\
\hline - interleukin 21 (IL-21) & NA & {$[74]$} \\
\hline \multicolumn{3}{|l|}{$\underline{\text { TNF family members }}$} \\
\hline - tumor necrosis factor a (TNF-a) & 207113_s_at & {$[75-78]$} \\
\hline - B cell activating factor (BAFF/TNFSF13B) & 223501_at & {$[9,79-82]$} \\
\hline $\begin{array}{l}\text { - A proliferation inducing ligand (APRIL/ } \\
\text { TNFSF13) }\end{array}$ & 210314_x_at & " " \\
\hline \multicolumn{3}{|l|}{ EGF family members $(* *)$} \\
\hline - amphiregulin (AREG) & 205239_at & {$[17,28]$} \\
\hline $\begin{array}{l}\text { - heparin-binding EGF-like growth factor } \\
\text { (HB-EGF) }\end{array}$ & 203821_at & {$[17,83,84]$} \\
\hline - neuregulin 1 (NRG1) & 208241_at & [17] \\
\hline - neuregulin 2 (NRG2) & 206879_s_at & " " \\
\hline - neuregulin 3 (NRG3) & 229233_at & " " \\
\hline - neuregulin 4 (NRG4) & 242426_at & " " \\
\hline
\end{tabular}


Table 1: List of growth factors investigated in the study. (Continued)

\begin{tabular}{|c|c|c|}
\hline \multicolumn{3}{|l|}{ FGF family members } \\
\hline $\begin{array}{l}\text { - fibroblast growth factor 2/basis FGF } \\
\text { (FGF2/bFGF) }\end{array}$ & 204422_s_at & {$[32,51]$} \\
\hline Wnt family members & & {$[47-49]$} \\
\hline- Wnt5A & 205990_s_at & \\
\hline - Wnt10B & NA & \\
\hline -Wnt16 & 224022_x_at & \\
\hline Jagged family & & [85-88] \\
\hline - Jagged 1 (JAG1) & 209099_x_at & \\
\hline - Jagged 2 (JAG2) & 32137_at & \\
\hline \multicolumn{3}{|l|}{ VEGF family } \\
\hline $\begin{array}{l}\text { - Vascular endothelial growth factor A } \\
\text { (VEGFA) }\end{array}$ & 212171_x_at & {$[31,89-92]$} \\
\hline
\end{tabular}

\section{B. Members of the VEGF, FGF, and Wnt family.}

\begin{tabular}{|c|c|}
\hline Growth factor & probe set \\
\hline \multicolumn{2}{|c|}{ VEGF family (5 members) } \\
\hline - VEGFA* & 212171_x_at \\
\hline - VEGFB & 203683_s_at \\
\hline - VEGFC & 209946_at \\
\hline - VEGFD/FIGF & NA \\
\hline \multicolumn{2}{|c|}{ FGF family members ( 22 members) } \\
\hline - FGF1 & 1552721_a_at \\
\hline - FGF2* & 204422_s_at \\
\hline - FGF3 & 214571_at \\
\hline - FGF4 & 206783_at \\
\hline - FGF5 & 210311_at \\
\hline - FGF6 & 208417_at \\
\hline - FGF7 & 230918_at \\
\hline - FGF8 & NA \\
\hline - FGF9 & 206404_at \\
\hline - FGF10 & NA \\
\hline - FGF11 & 227271_at \\
\hline - FGF12 & 1562794_at \\
\hline - FGF13 & 205110_s_at \\
\hline - FGF14 & 231523_at \\
\hline - FGF16 & NA \\
\hline - FGF17 & NA \\
\hline - FGF18 & 231382_at \\
\hline
\end{tabular}


Table 1: List of growth factors investigated in the study. (Continued)

\begin{tabular}{|c|c|}
\hline - FGF19\# & NA \\
\hline - FGF20 & NA \\
\hline - FGF21 & NA \\
\hline - FGF22 & NA \\
\hline - FGF23 & NA \\
\hline \multicolumn{2}{|c|}{ Wnt family members (19 members) } \\
\hline- Wnt1 & NA \\
\hline -Wnt2 & 205648_at \\
\hline$-W n t 2 B$ & NA \\
\hline- Wnt3 & 229103_at \\
\hline$-W n t 3 A$ & $N A^{\psi}$ \\
\hline- Wnt4 & 208606_s_at \\
\hline- Wnt5 $A^{*}$ & 205990_s_at \\
\hline- Wnt5B & 221029_s_at \\
\hline- Wnt6 & 71933_at \\
\hline- Wnt7A & 210248_at \\
\hline- Wnt7B & NA \\
\hline- Wnt8A & 224259_at \\
\hline- Wnt8B & NA \\
\hline- Wnt9A & NA \\
\hline- Wnt9B & NA \\
\hline- Wnt10A & 223709_s_at \\
\hline- Wnt10B* & NA \\
\hline- Wnt11 & 206737_at \\
\hline- Wnt16* & 224022_x_at \\
\hline
\end{tabular}

A. $\left({ }^{*}\right)$ The list of references is not exhaustive, and includes the original or major studies. $\left.{ }^{* *}\right)$ Among all ten EGF-family members, only those having a heparin-binding domain are listed here. Indeed, only EGF-ligands that bind the HSPG syndecan-1 present on MMC can stimulate myeloma cell growth [17]. Probe sets noted "NA" were considered to be "non-informative" (see additional file 1).

B. * Indicates that the growth factor has already been reported to be involved in myeloma biology (they are also listed in table 1A). \#FG19 is the human orthologue of FGF15 and was cloned by homology to mouse FGF15. ${ }^{\psi}$ Indicates that no probe set was found for this gene. Probe sets noted "NA" were considered to be "non-informative" (see additional file 1).

and $\mathrm{CD} 3+\mathrm{T}$ cells, as well as in in vitro-generated bone marrow stromal cells (BMSC) and osteoclasts. We provide for the first time a comprehensive overview of growth factor expression in the different BM cell populations of patients with MM.

\section{Methods}

\section{Patients and cell samples}

Samples were obtained in agreement to the French and German ethical laws. MMC were purified from the BM of 131 patients with newly-diagnosed MM (median age, 59 years) after written informed consent was given. The study has been approved by the ethic boards of Heidelberg University and Montpellier University hospitals. According to Durie-Salmon classification, 14 patients were of stage IA, 24 of stage IIA, 76 of stage IIIA, 14 of stage IIIB, one had a plasma cell leukaemia and 2 were of undetermined stage. Human normal bone marrow samples were obtained from filtration residues of the bone marrow harvested from healthy donors for stem cell allograft after agreement of the Center of Biological Resources of the Montpellier University Hospital. Buffy coats of peripheral blood cells were purchased from the French Blood Center according to a written approved convention between French Blood Center and Montpellier University Hospital. Normal BM plasma cell (BMPC) and primary $\mathrm{MMC}$ were purified using using autoMACS with anti-CD138 MACS microbeads (Miltenyi-Biotec, Paris, France) as previously described [9]. For the isolation of peripheral blood memory B cells (MB), monocytes, NK and T cells were first removed using antiCD14, anti-CD16 and anti-CD3 magnetic beads (Dynal), 
and $\mathrm{MB}$ cells were then positively selected using antiCD27 MACS microbeads (Miltenyi Biotec). Polyclonal plasmablasts (PPC) were generated from purified peripheral blood CD19+ B cells in vitro, as described $[10,11]$. Whole BM samples (WBM) were obtained from 75 of the 131 patients with MM whose MMC were purified. According to the Durie-Salmon classification, 12 patients were in stage IA, 15 in stage IIA, 45 in stage IIIA, three in stage IIIB. In addition, BM $\mathrm{T}$ lymphocytes (CD3+), monocytes (CD14+) and polymorphonuclear neutrophils (PMN, CD15+) were simultaneously purified from the BM of five of those 75 patients, as described previously [9]. Stromal cells (BMSC, $n=5)$ and osteoclasts $(n=7)$, which cannot be harvested in BM aspirates, were generated in vitro from the BM of MM patients, as described [9].

\section{Preparation of complementary RNA (cRNA), microarray hybridization and gene expression profiling analysis}

Microarray experiments were performed at the Institute of Research in Biotherapy http://irb.chu-montpellier.fr/ en/laboratories microarray.html in the Montpellier University Hospital. RNA was extracted with the RNeasy Kit (Qiagen) or the SV-total RNA extraction kit (Promega) and Trizol (Invitrogen), in accordance with the manufacturer's instructions. Biotinylated complementary RNA (cRNA) was amplified with a double in-vitro transcription, according to the Affymetrix small sample labelling protocol vII (Affymetrix). The biotinylated cRNA was fragmented and hybridized to the HG-U133 Plus 2.0 GeneChip oligonucleotide arrays according to manufacturer's instructions (Affymetrix). Fluorescence intensities were quantified and analyzed using the GCOS software (Affymetrix). Arrays were scaled to an average intensity of 100. A threshold of 1 was assigned to values under 1 . Gene expression data were analysed with our bioinformatics platforms: RAGE, http://rage.montp.inserm.fr[12] and "Amazonia!", http://amazonia.montp.inserm.fr[13].

All microarray data presented in this paper have been deposited in the ArrayExpress public database, under accession numbers E-MEXP-2360 for BMPC [11] and ETABM-937 for B cells, PPC, MMC and environment population samples. We also used Affymetrix data of 22 normal BMPC samples and a cohort of 345 purified MMC from previously-untreated patients from the Arkansas Research Group (Little Rock) $[14,15]$. These data are publicly available in the NIH Gene Expression Omnibus (GEO) http://www.ncbi.nlm.nih.gov/geo/ under accession number GSE2658 for MMC samples and GSE5900 for 22 normal BMPC.

\section{Statistical analysis}

For supervised analyses, differentially expressed genes were identified by a student t-test, and $p$-values were adjusted for multiple comparisons using the Benjamini and Hochberg correction. The threshold for significance was set to a $p$ value $\leq 0.05$. Among those genes, those with a fold change $\geq 2$ were retained. Among the genes found to be statistically overexpressed with a fold change $\geq 2$ in a given population, those with $100 \%$ absent call in this population were considered not to be biologically relevant and were removed. The call ("present" or "absent") is determined by Affymetrix GCOS-software and indicates whether a gene is reliably expressed or not. Regarding analysis on the different environment populations, whole bone marrow samples (WBM) were not included for supervised analysis. They include both MMC and environment cells and the expression of a given gene could be the reflection of its expression in MMC or in the environment or both.

\section{Results}

Affymetrix microarrays to investigate Myeloma Growth Factor (MGF) expression in BM subpopulations

Based on the literature data, we have listed 32 growth factors that have already been described as growth factors for MMC (Table A1A). As VEGFs, Wnts and FGFs are members of families with strong homologies, we extended the study to all members of those families, even if only some of them have already been shown to play a role in MM (Table B1B). Gene expression of 24/32 known MGF, 3/4 VEGFs, 13/22 FGFs and 11/19 Wnts could be interrogated with Affymetrix U133 Plus 2.0 arrays (Tables A1A and B1B). Other genes could not be studied due to a lack of probe set (one gene: Wnt3A) or to a "noninformative" probe set, i.e. with a low signal and an absent call in $\geq 95 \%$ of the samples (20 genes, see additional file 1 ). Thus 51 growth factors could be interrogated by 147 probe sets. When several probe sets were available for a given gene, the probe set with the highest percentage of "present call" among all samples or the one with the highest variance in case of $100 \%$ presence was selected. Probe sets are listed in Tables A1A and B1B.

\section{The majority of MGF are overexpressed in the tumor environment compared to MMC}

In order to identify which MGF are expressed by each cell component of the BM, we compared the expression of the 51 MGF genes among all BM subpopulations. 3/51 MGF genes - FGF7, NRG3, Wnt10A - were statistically significantly overexpressed in purified myeloma cells (MMC, $\mathrm{n}$ = 131) compared to each other BM population: $\mathrm{T}$ cells (CD3, $\mathrm{n}=5$ ), monocytes (CD14, $\mathrm{n}=5$ ), CD15+ polymorphonuclear neutrophils ( $\mathrm{PMN}, \mathrm{n}=5$ ), bone marrow stromal cells (BMSC, $\mathrm{n}=5)$, and osteoclasts $(\mathrm{n}=7)(\mathrm{p} \leq$ .05 , fold-change $\geq 2$ ). They were defined as "myeloma MGF" (Figure 1 and additional file 2, table S-I). 22/51 genes were overexpressed in cells from the environment 
compared MMC ( $\leq .05$, fold-change $\geq 2$ ). 14 out of those 22 MGF genes were overexpressed in cells of the putative tumor niche, i.e BMSC (11 genes) and osteoclasts (3 genes), compared to MMC and other BM subpopulations (CD3, CD14 and PMN). They were defined as "myeloma niche MGF" (Figure 1 and additional file 2, table S-II). 8/22 genes were overexpressed in at least one $\mathrm{BM}$ subpopulation (CD3, CD14 and/or PMN) compared to MMC, BMSC and osteoclasts $(\mathrm{p} \leq .05$, fold-change $\geq$ 2). They were defined as "environment MGF" (Figure 1 and additional file 2, table S-III). 17/51 genes were not classified by the supervised analysis. For the majority of them (12 genes), the reason is that they were highly expressed both in MMC and in at least one environment population (Figure 1 and additional file 2, table S-IV). The five remaining genes (NRG2, Wnt4, Wnt11, Wnt16 and FGF18) were considered as a "myeloma MGF" although they were not statistically significantly overexpressed in MMC compared to environment cell populations. Indeed, they displayed a present call in some of the MMC samples whereas they were absent in all other BM populations (see additional file 2, table S-I). Finally, 9/51 MGF were not/weakly expressed, neither in MMC nor in the environment. They had less that $5 \%$ of presence in MMC samples and BM subpopulations and they were not expressed in BMSC and osteoclasts (data not shown). Those genes include 5 members of the FGF family (FGF3,4,6,11,14), 3 members of the Wnt family (Wnt2A,7A,8A) and NRG4. This lack of expression could not be attributed to a lack of detection by a non-functional Affymetrix probe set, as expression of these genes could be detected using Affymetrix microarrays in various normal tissues (data not shown, see additional file 1). Altogether, those data indicate that the majority of MGF are overexpressed by the environment compared to MMC, and suggest that BMSC are the main source of MGF.

\section{MGF genes overexpressed in MMC compared to the environment}

The 3 "myeloma MGF" as well as FGF18, NRG2, Wnt4, Wnt11 and Wnt16 (100\% absent call in all environment populations) are represented in Figure 2. For clarity of the presentation, only 44/131 MMC samples as well as 44 whole BM samples (including MMC and cells of the environment; WBM), both obtained from the same patients, are depicted here. "Myeloma MGF" include 2 members of the EGF family (NRG2 and NRG3), 2 members of the FGF family (FGF7 and FGF18) and 4 members of the Wnt family (Wnt4, Wnt10A, Wnt11 and Wnt16). Except for FGF7, those 8 MGF displayed $100 \%$ absent call in all other BM cell populations (table S-I). Hence, the expression detected in the WBM samples is due to the MMC (Figure 2, right panel) and those factors are exclusively autocrine for the MMC. Three of these 8 genes - FGF7, Wnt4 and Wnt10A - were also expressed in normal plasma cells (Figure 2).

\section{MGF genes overexpressed in cells of a putative myeloma niche, i.e BMSC and osteoclasts, compared to MMC and other BM subpopulations}

The 14 "myeloma niche" MGF are represented in Figure 3. 11/14 genes were overexpressed in BMSC compared to all other $\mathrm{BM}$ populations ( $\mathrm{p} \leq .05$, fold-change $\geq 2$ ): BNDF, 3 members of the FGF family (FGF1, FGF2, FGF5), GDF15, IL-6, JAG1, LIF, VEGFC and 2 members of the Wnt family (Wnt3 and Wnt5B) (Figure 3A). 3/14 genes were overexpressed in osteoclasts compared to all other BM populations ( $\mathrm{p} \leq .05$, fold-change $\geq 2$ ): IGF1, IL10 and April (Figure 3B). IGF-1 and IL-6 have been extensively described as paracrine myeloma growth factors $[5,6]$. Accordingly, they belong to the "myeloma niche" category. Interestingly, IL-6 and IGF-1 were also expressed by the MMC themselves, in $60 \%$ and $100 \%$ of the patients, respectively (\% of present call, table S-II), but at a lower level than in BMSC for IL-6 (median IL-6 expression in $\mathrm{MMC}=55$, versus 1867 in BMSC, table SII) and in osteoclasts for IGF-1 (median IGF-1 expression in $\mathrm{MMC}=424$, versus 1104 in osteoclasts, table S-II).

\section{MGF genes overexpressed in cell subpopulations of the} environment compared to MMC, BMSC and osteoclasts

The 8 "environment" MGF are represented in figure 4A and listed in additional file 2, Table S-III. CD14-positive monocytes overexpressed 6/8 "environment" MGF ( $p \leq$ .05 , fold-change $\geq 2$ ): 2 TNF-superfamilly members (TNFSF13B/BAFF and TNF- $\alpha$ ), OSM, IL-1 $\beta$, IL15 and HB-EGF. CD15-positive PMN also overexpressed BAFF and OSM, as well as FGF13, compared to MMC, BMSC and osteoclasts. Thus, monocytes and PMN may be an important source of growth factors for the tumor, especially because PMN represent around $50 \%$ of the cells in the BM [16]. CD3+ T cells overexpressed FGF9 (Table SIII).

\section{MGF genes expressed both by MMC and the environment}

$12 / 51$ genes were not classified by the supervised analysis (Table S-IV). For seven of them, the reason is that they were highly expressed both in MMC and in at least one environment cell population: AREG, Wnt5A, CCL3, CLCF1, VEGF, FGF12 and HGF (Figure 4B and table SIV). AREG was expressed in MMC and WBM samples, as well as in CD3, CD14 and PMN subpopulations, but it was weakly or not expressed by BMSC and osteoclasts. In contrast, Wnt5A was not expressed in WBM samples and in the subpopulations, but it was expressed in osteoclasts and BMSC. It should be noted that HGF expression in MMC (median $=218$ ) was not significantly higher that 


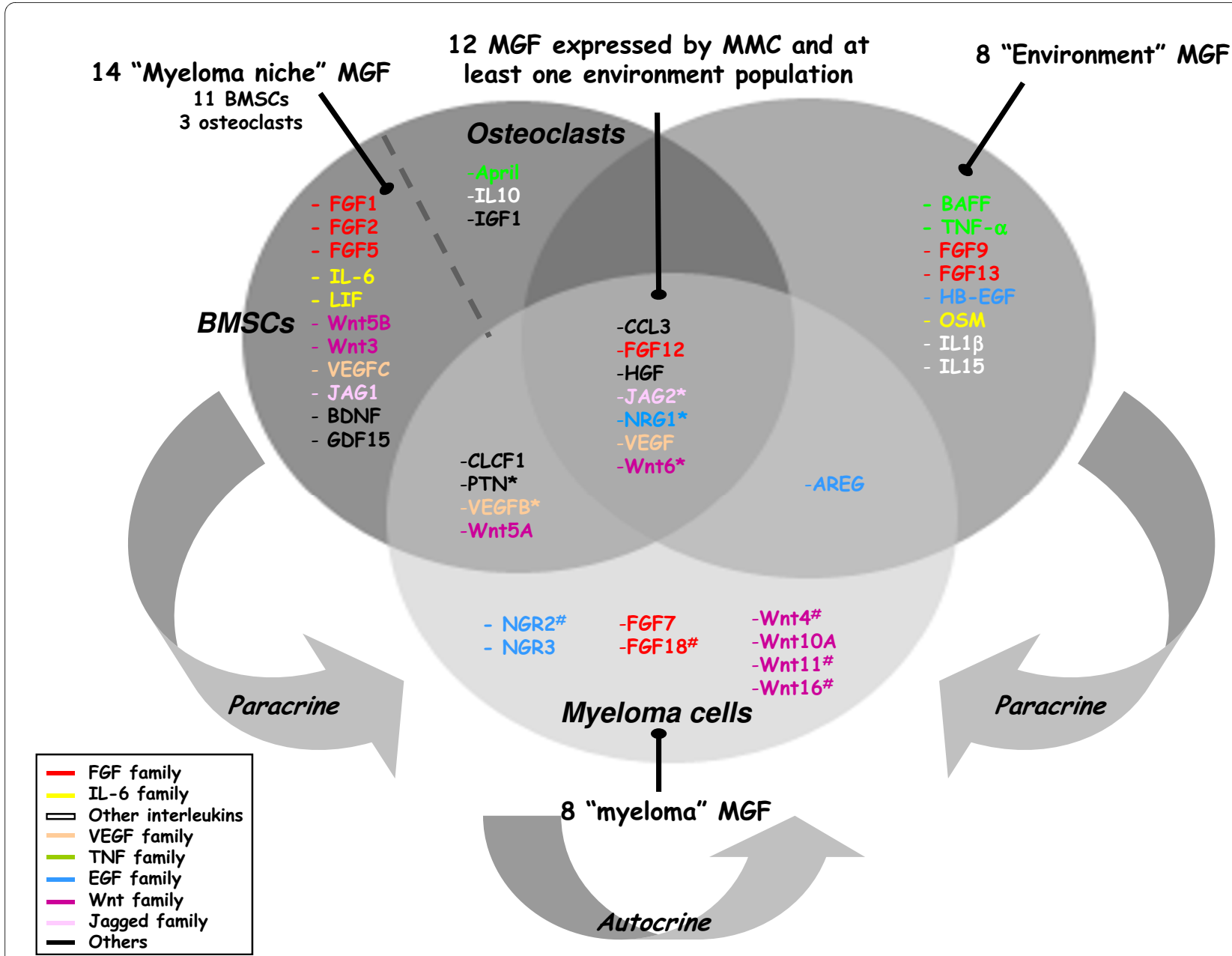

Figure 1 The majority of MGF is expressed by the BM environment of patients with MM. 42/51 MGF genes that are expressed in MMC and/or in the environment are represented in a Venn diagram according to their overexpression in each BM population compared to the others ( $p \leq .05$, foldchange $\geq 2$ ). *Indicates that those 5 genes were expressed in MMC and environment cells, but without any change in signal between present or absent call (data not shown). This suggests that either those probe sets poorly work or their expression level is at the limit of sensitivity and thus can hardly be detected by Affymetrix probe sets. \#Those genes were not statistically significantly overexpressed in MMC, but they displayed an absent call in all environment population (see additional file 2, table S-I) and they were thus defined as "myeloma MGF".

that in BMSC $($ median $=194, \mathrm{p}=0.4), \mathrm{CD} 14$ (median $=$ 99, $\mathrm{p}=0.1$ ) and PMN (median $=102, \mathrm{p}=0.1$ ). However, HGF expression in MMC among 131 patients was very heterogeneous and it could be very high in some patients' MMC (range 1 to 5378). Other 5 genes (PTN, NRG1, JAG2, VEGFB and Wnt6) were also expressed in MMC and environment cells, but without any change in signal between present or absent call (data not shown). This may suggest that those probe sets poorly work. It may also be that the expression level is at the limit of sensitivity and thus can hardly be detected by Affymetrix probe sets. This is likely the case for NRG1 whose gene expression measured by real-time PCR has been already documented in MM [17].

\section{Growth factor receptor expression in MMC}

Because the aim of this study was to describe the expression of growth factors that sustain myeloma cell growth through paracrine or autocrine stimulation, we focused on the analysis of receptor expression in MMC only. However, we cannot exclude that MGF receptor expression by cells from the environment (data not shown) could indirectly influence myeloma cell growth as well. Among 48 MGF receptors that are listed in Table 2, 36 could be interrogated with Affymetrix microarrays. Half of the MGF receptor genes (18/36) were expressed in more than $50 \%$ of the MMC samples (present call, Table 2). Among them, $4 \mathrm{MGF}$ receptor genes were expressed in $100 \%$ of the patients (IL-6ST, IL-10 RB, BCMA or 
A.

PC differentiation and myeloma

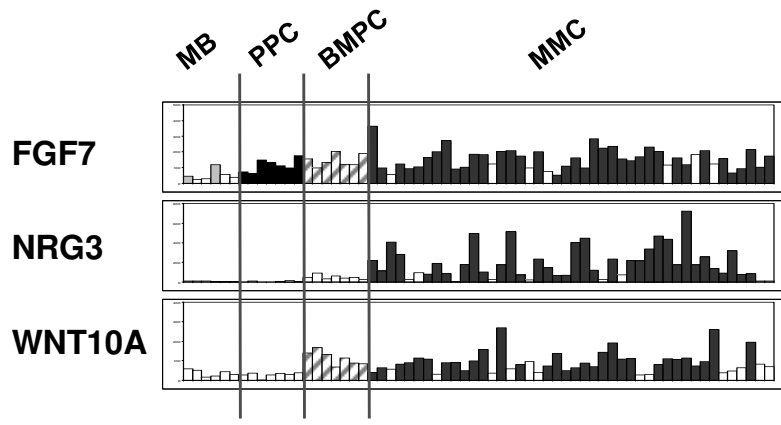

B.

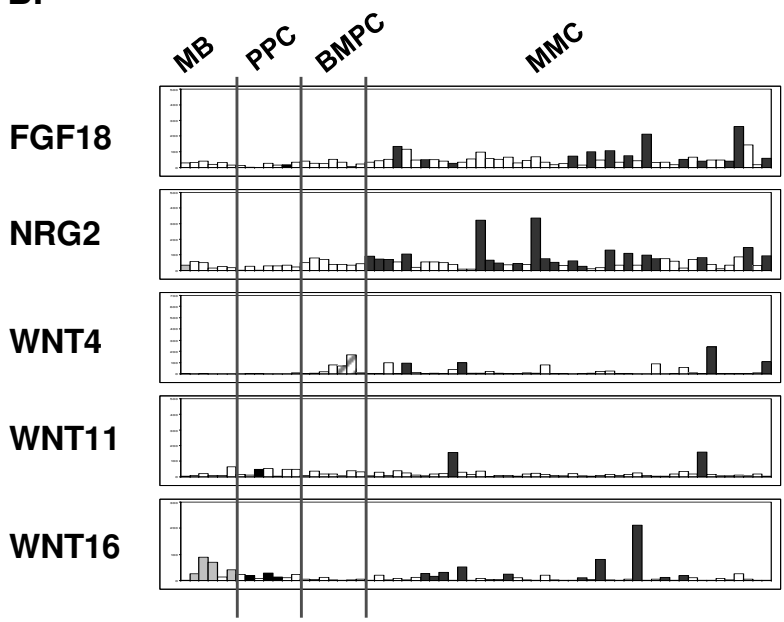

BM microenvironment

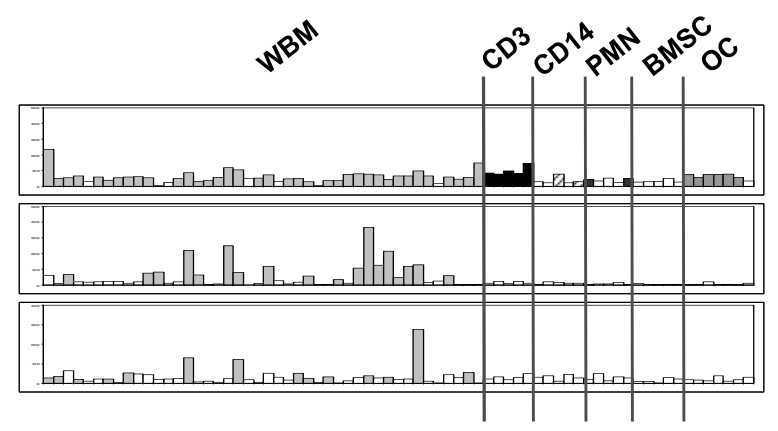

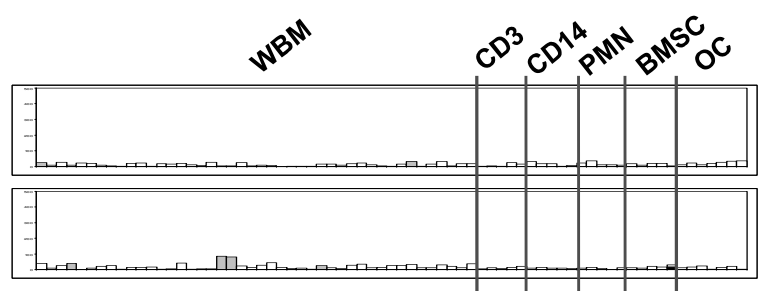

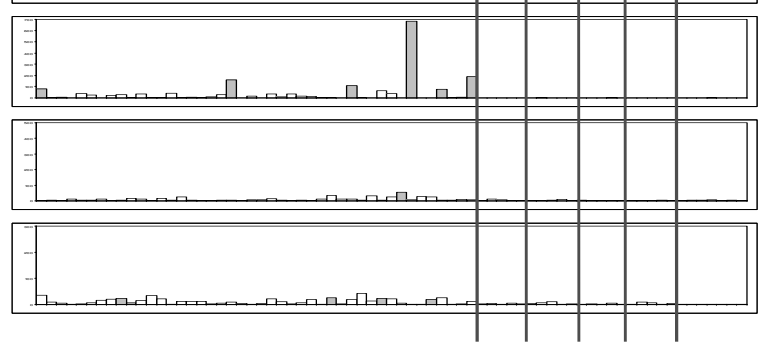

Figure 2 Gene expression of "myeloma MGF" in bone marrow subpopulations. (A) Overexpressed genes in MMC versus CD14, PMN, CD3, BMSCS and osteoclasts ( $p \leq .05$, fold-change $\geq 2$ ). (B) MMC genes that were not statistically significantly overexpressed in MMC but displayed an absent call in all environment population (see additional file 2, table S-I). Histograms show the gene signal intensity on the $Y$ axis as arbitrary units determined by the Affymetrix software. Each histogram features the same samples: 6 MB, 7 PPC, 7 BMPC, 44 MMC, 44 WBM, 5 CD3+/CD14+/PMN samples from newly diagnosed myeloma patients, 5 BMSC and 7 osteoclast samples generated in vitro. Expression data of $131 \mathrm{MMC}$ samples and 75 WBM samples are presented in additional file 2. For clarity of the presentation, only 44/131 MMC and 44/75 WBM, both obtained from the same patients, are depicted here. White bars indicates that the gene displays an "absent" detection call. Abbreviations: MB, memory B cells; PPC, plasmablasts; BMPC, bone marrow plasma cells; MMC, myeloma cells, WBM, whole BM; CD3, T cells; CD14, monocytes; PMN, polymorphonuclear neutrophils; BMSC, stromal cells; OC, osteoclasts.

Notch 2), 1 MGF receptor gene was expressed in $99 \%$ of them (IL-6R) and 5 MGF receptor genes were expressed in more than $90 \%$ of the patients (IL-10RA, TACI and Frz receptors 4,7 and 9). This indicates that the vast majority of the patients, if not all, have receptors for IL-6, IL-10, Baff/April and Wnt. 14/36 MGF receptor genes were expressed in $10-50 \%$ of the patients and $4 / 36$ of them were expressed in less than $10 \%$ of the patients (table 2). CLCF1R was absent is $100 \%$ of the MMC samples and IL1R in $99 \%$ of them (in agreement with previous data [18]), suggesting that their respective ligands produced by the environment (see figure 4) have no biological relevance to MMC.

\section{Expression of MGF and MGF receptors throughout normal PC differentiation and in MMC}

In order to investigate the expression of MGF and MGF receptors throughout normal PC differentiation and in the generation of malignant plasma cells, we compared the expression of the $51 \mathrm{MGF}$ and $36 \mathrm{MGF}$ receptor genes in memory $B$ cells $(\mathrm{MB}, \mathrm{n}=6)$, in in vitro-generated plasmablasts $(\mathrm{PPC}, \mathrm{n}=7)$ in purified bone marrow plasma 
A.

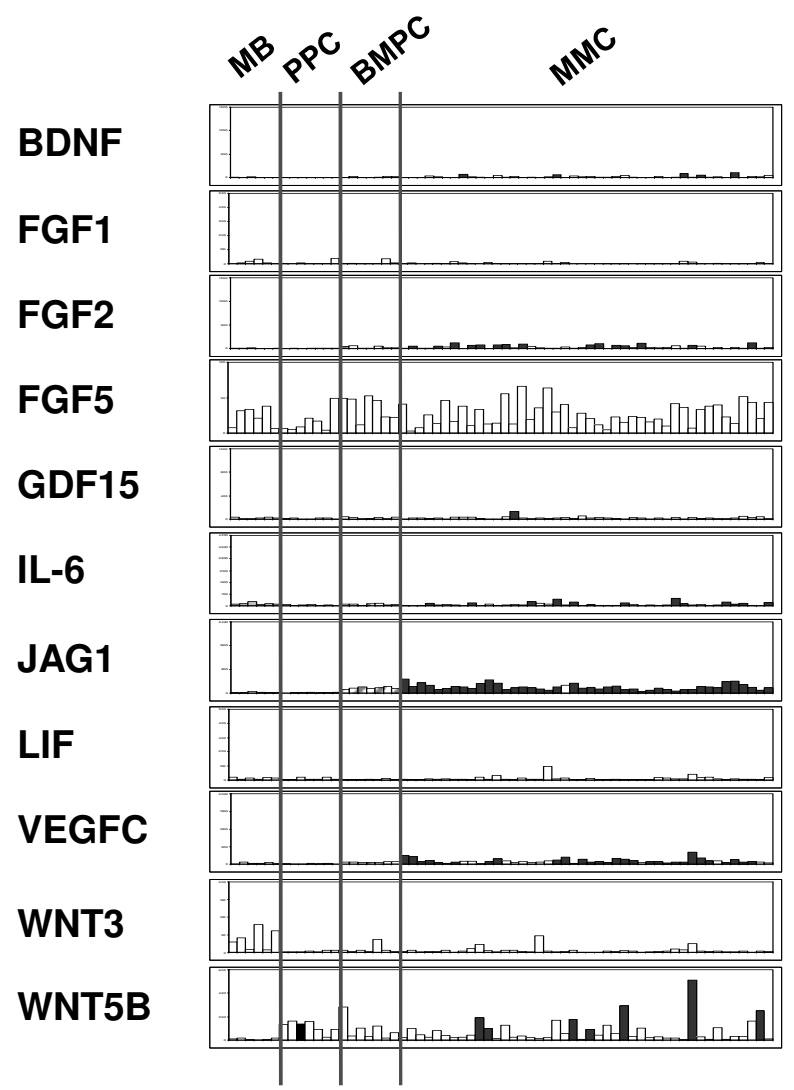

B.

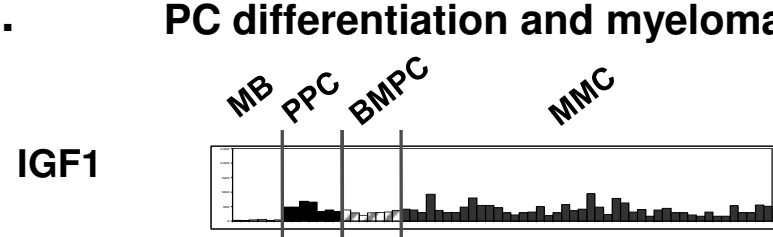

IL10

TNFSF13/ April

PC differentiation and myeloma
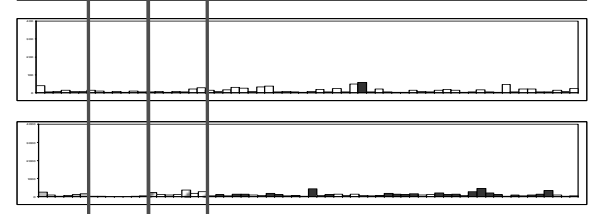

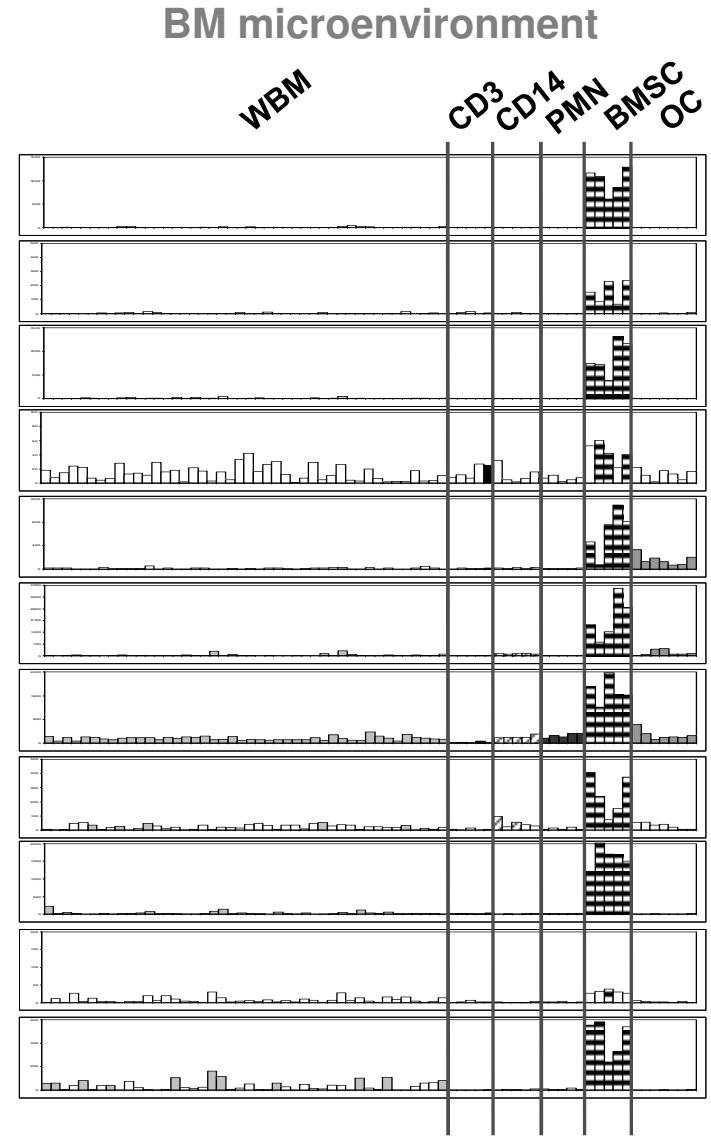

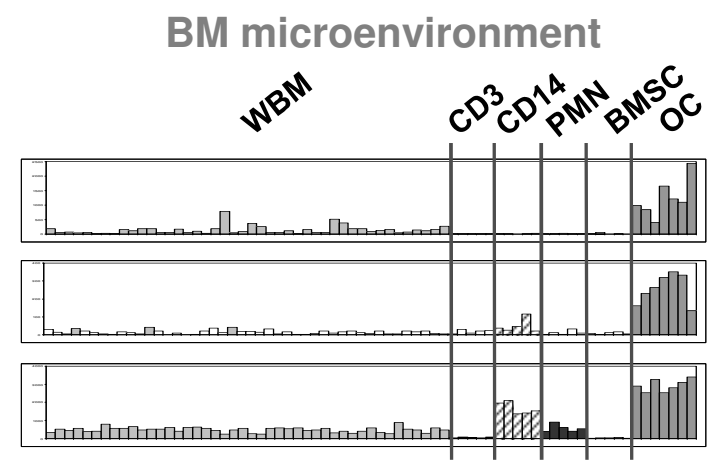

Figure 3 Gene expression of "myeloma niche MGF" in bone marrow subpopulations. Genes overexpressed in BMSCs (A) and in osteoclasts (B) versus CD14, PMN, CD3 and MMC ( $p \leq .05$, fold-change $\geq 2)$. See also legend of Figure 2

cells (BMPC, $\mathrm{n}=7)$, and MMC $(\mathrm{n}=131)$. Data are shown in additional file 3, figures S-I and S-II and additional file 2 , tables S-V and S-VI. The expression of $8 \mathrm{MGF}$ and 10 MGF receptor genes was statistically significantly different between B cells and "PPC+BMPC" ( $p \leq .05$, fold- change $\geq 2$ ). 4 MGF genes (OSM, Wnt6, Wnt16 and FGF9) were up-regulated in B cells, whereas others 4 (FGF7, CCL3, Wnt5B and IGF1) were up-regulated in "PPC+BMPC". 1 MGF receptor gene (IL10RA) was upregulated in $\mathrm{B}$ cells, whereas other 9 genes were up-regu- 
lated in "PPC+BMPC" ( $\leq .05$, fold-change $\geq 2): 3$ FRZfamily members (FRZ1,3,6), the 2 members of the IL6R complex (IL-6R and IL-6ST), IL15RA, Met, TNFRSF17 and IL21R.

Interestingly, the expression of $12 \mathrm{MGF}$ and 12 receptors was significantly different between PPC and BMPC, 11/12 MGF and 11/12 MGF receptor genes being up-regulated in BMPC compared to PPC ( $\mathrm{p} \leq .05$, fold-change $\geq$ 2; figures S-I and S-II). Those 11 MGF genes include 2 Wnt-family members (Wnt5A, Wnt10A), 2 VEGF-family members (VEGFB and C), 1 FGF-family member (FGF2), 1 EGF-family members (AREG), 2 TNF-family members (Baff, April), PTN, CCL3 and JAG1. MGF receptor genes comprise 5 members of the FRZ family (FRZ1,2,6,7,8), IL6ST, NTRK2, Notch4, TNFRSF1A, CCR1 and LIFR. IL21R was upregulated in PPC. These data emphasize an increased expression of genes encoding for MGF and their receptors throughout plasma cell differentiation, in particular during late plasma cell stage, i.e in BMPC. It is noteworthy that FRZ receptor expression is a hallmark of PC differentiation.

We then compared the expression of the $51 \mathrm{MGF}$ and 36 receptor genes in MMC and in BMPC. Only 3 MGF and 1 MGF receptor gene (FZD2) were significantly differentially expressed between MMC and BMPC ( $1 \leq .05$, fold-change $\geq 2$ ). FZD2 was overexpressed in BMPC, whereas all three MGF genes were overexpressed in MMC: AREG, NRG3 and Wnt5A. AREG and WNT5A were also upregulated in BMPC compared to PPC. In contrast, NRG3 was not expressed in any normal population (100\% absent call) but it was expressed in $73 \%$ of the patients'samples with a very strong signal in some of them (see Figure 2). Those 3 MGF genes were also found to be overexpressed in MMC versus BMPC ( $\leq \leq .05$, foldchange $\geq 2$ ) in an independent publicly available data set of $22 \mathrm{BMPC}$ and $345 \mathrm{MMC}$ patients' samples from the Arkansas Research Group (Little Rock, additional file 2, table SVII-A). Of note, 10/51 MGF and 5/36 receptor genes were "absent" in all BMPC samples (data not shown) whereas they were expressed in more than $10 \%$ (present call) of the MMC samples (see additional file 2). Hence, they may also be considered as being aberrantly expressed in MMC compared to normal BMPC although they are not statistically significantly overexpressed in MMC. Those MGF genes include HGF, 2 EGF-family members (HB-EGF and NRG2), 3 Wnt-family members (Wnt5B, Wnt11, Wnt16), 2 FGF-family members (FGF9, FGF18), BDNF and TNF- $\alpha$ (data not shown). MGF receptor genes include FGFR3, IL11R, IGF1R, FRZ4 and LRP6. Additional normal samples would be required to conclude about their relative expression in normal versus tumor cells. Among them, one MGF (HGF) and one MGF receptor (IL-11R) genes were statistically significantly overexpressed in MMC versus BMPC in the publicly available data set of $22 \mathrm{BMPC}$ and 345 MMC patients' samples ( $\mathrm{p} \leq .05$, fold-change $\geq 2$; additional file 2 , table S-VII).

\section{Discussion}

Two major messages arise from this study. 1) The majority of MGF genes is expressed by the bone marrow environment. 2) Several MGF and their receptors are overexpressed throughout normal plasma cell differentiation.

22 out of the 51 MGF genes that could be interrogated by Affymetrix were significantly overexpressed by at least one BM environment population compared to others and to $\mathrm{MMC}$, whereas only 3 of them were significantly overexpressed in MMC compared to the environment. These data emphasize the importance of the tumor microenvironment in MM pathogenesis. Purified primary MMC rapidly undergo apoptosis as soon as they are purified, suggesting that MGF produced by MMC themselves are not sufficient to maintain their survival [19]. The environment niche for MMC is not elucidated presently. It may resemble the normal plasma cell niche which comprises SDF-1-producing stromal cells and that is shared with hematopoietic stem cells and pre pro B cells [20]. Several studies have confirmed the importance of the endosteal cells, in particular BMSC (differentiated or not into osteoblasts) and osteoclasts to support myeloma cell proliferation and survival $[21,22]$. Other cells of the BM environment (CD14, CD3, PMN) and minor populations like plasmacytoid dendritic cells [23] could be important as well. In this study, we show that BMSC and osteoclasts are the main source of MGF. They highly express 11/21 and 3/21 "environment" MGF genes, respectively, in particular MGF that have been reproducibly identified in several studies: IGF-1, IL-6, APRIL, IL-10 [3]. In addition, these two cell types produce complementary sets of MGF, insuring that the endosteal niche could provide an optimal cocktail of growth factors for MMC survival. A point to emphasize is that MMC may progressively select a tumor-promoting environment. We have shown that BMSC from MM patients (MM-BMSC) support the growth of a stroma-dependent myeloma cell line better than normal BMSC and show a reduced matrix mineralisation capability [24]. Furthermore, BMSC from MM patients and from normal donors have a distinctive gene expression profile on microarrays analysis [24]. The fact that MM-BMSC have a specific gene signature although they have been cultured in vitro for several days in the absence of malignant plasma cells (cells are harvested after 41 days of culture for microarrays analysis [24]) suggest that cells harvested from the bone marrow microenvironment of myeloma patients keep their specific features even after in vitro culture. The second interesting finding is that MGF and MGF receptor gene expres- 


\section{A.

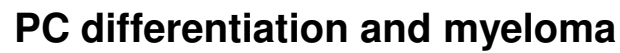

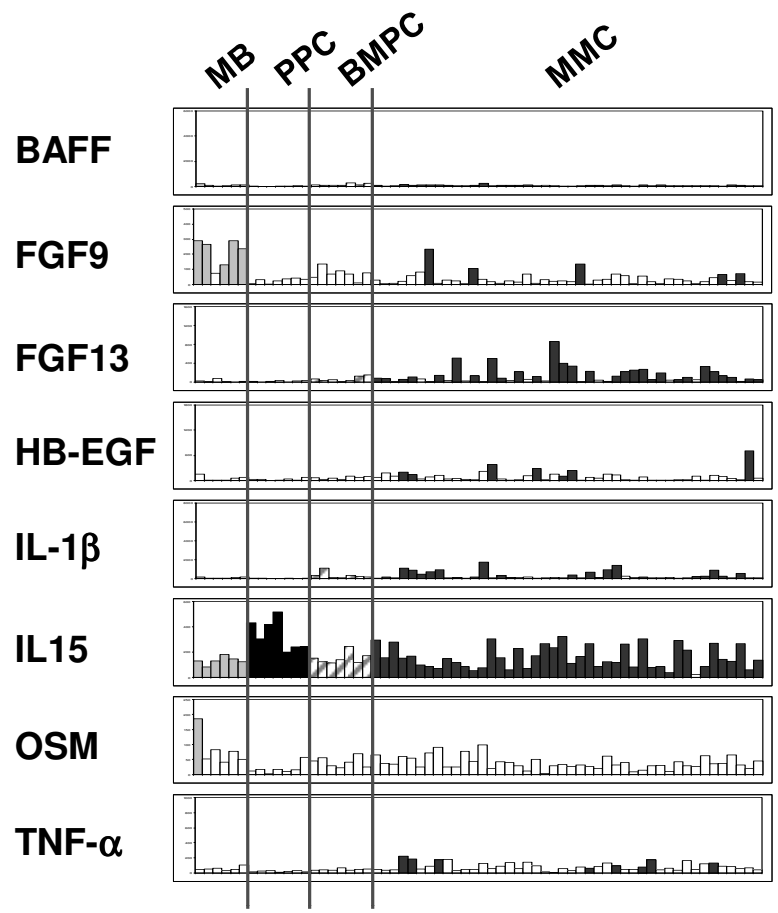

B.

PC differentiation and myeloma

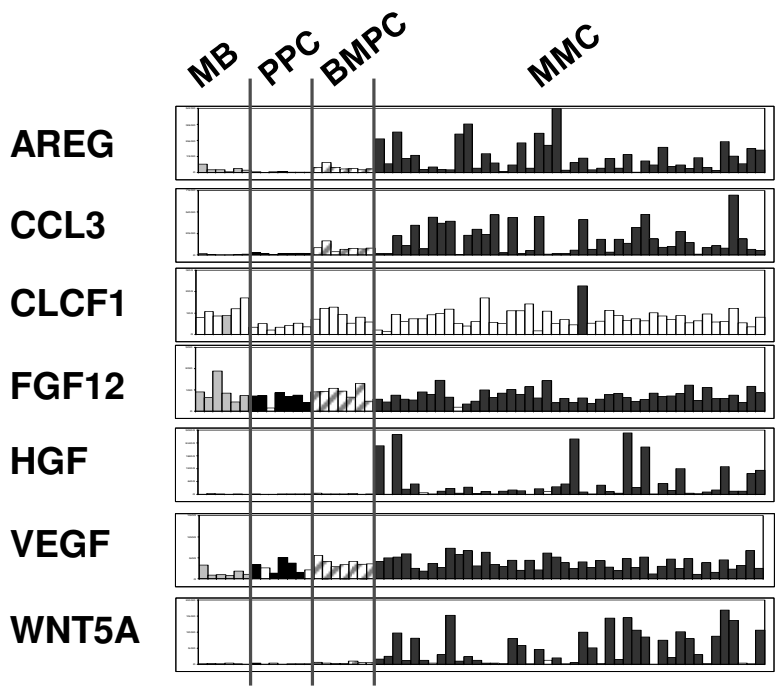

BM microenvironment

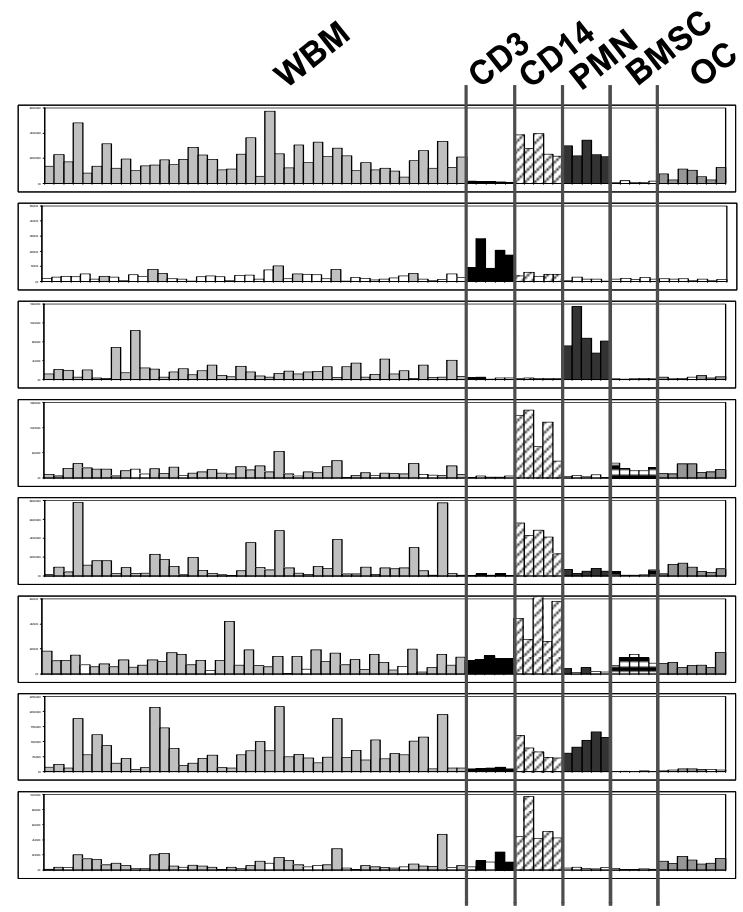

BM microenvironment

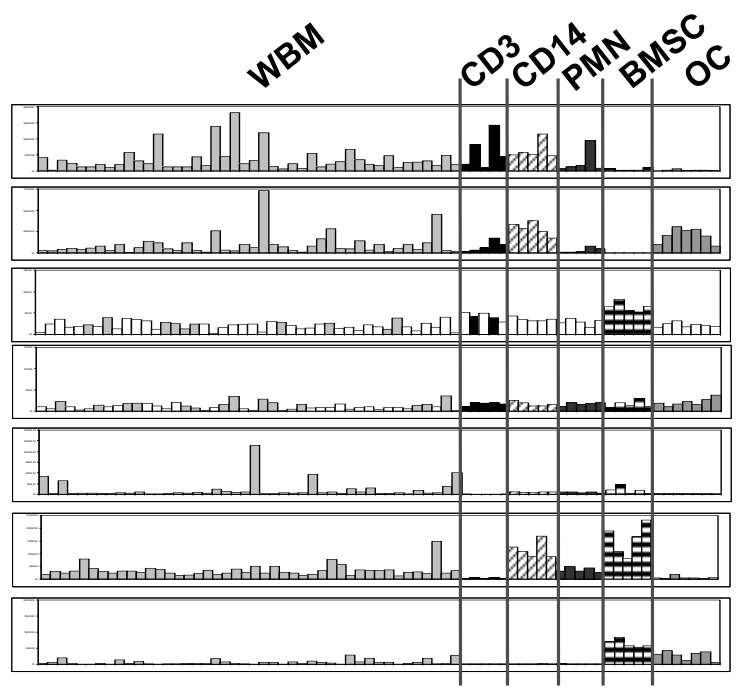

Figure 4 Gene expression of "environment MGF", and MGF expressed both in MMC and in the environment. (A) Genes overexpressed in at least one of the population CD14, PMN, CD3 versus MMC, BMSCs and Ocs ( $p \leq .05$, fold-change $\geq 2$ ). (B) MGF genes that were not statistically significantly overexpressed in any of the BM populations. They were expressed in MMC and at least one the environment subpopulation. See also legend of Figure 2 . 
Table 2: Affymetrix expression of growth factor receptor genes in MMC.

\begin{tabular}{|c|c|c|c|c|}
\hline MFG & MGF receptor & probeset & $\begin{array}{l}\text { Median (range) } \\
\text { on MMC } \\
(n=131)\end{array}$ & $\begin{array}{l}P(\%) \\
\text { on MMC } \\
(n=131)\end{array}$ \\
\hline- IGF-1 & - IGF-1R & 203627_at & $19(1-85)$ & 32 \\
\hline - HGF & - c-Met & 203510_at & $78(4-728)$ & 50 \\
\hline$-\mathrm{CCL} 3$ & $-\mathrm{CCR} 1$ & 205098_at & $136(26-2840)$ & 78 \\
\hline - GDF15 & - not known & --- & --- & --- \\
\hline - PTN & - RPTP- $\beta / \zeta /$ & 204469_at & $24(1-1958)$ & 48 \\
\hline- BDNF & - NTRK2 & 207152_at & $84(4-286)$ & 77 \\
\hline \multicolumn{5}{|l|}{ IL-6 family } \\
\hline \multirow[t]{2}{*}{ - IL-6 } & - IL-6R (gp80) & 205945_at & $502(7-3657)$ & 99 \\
\hline & - IL6ST (gp130) & 212195_at & $1681(210-5680)$ & 100 \\
\hline - CNTF & - CNTFR & NA & --- & --- \\
\hline - OSM & - OSMR & 205729_at & $25(1-88)$ & 58 \\
\hline - LIF & - LIFR & 225575_at & $16(1-203)$ & 15 \\
\hline- IL-11 & $-I L-11 R$ & 204773_at & $61(3-140)$ & 26 \\
\hline - CLCF1 & - CRLF1 & 206315_at & $15(2-91)$ & 0 \\
\hline \multicolumn{5}{|c|}{ other interleukins } \\
\hline$-I L-1 \beta$ & $-I L-1 R$ & 202948_at & $10(1-63)$ & 1 \\
\hline \multirow[t]{2}{*}{$-I L-10$} & - IL-10RA & 204912_at & $212(24-912)$ & 92 \\
\hline & - IL-10RB & 209575_at & $240(98-536)$ & 100 \\
\hline- IL-15 & - IL-15R & 207375_s_at & $142(16-403)$ & 55 \\
\hline$-\mathrm{IL}-21$ & $-\mathrm{IL}-21 \mathrm{R}$ & 221658_s_at & $6(1-395)$ & 5 \\
\hline \multicolumn{5}{|l|}{ TNF family } \\
\hline - TNF-a & - TNFRSF1A & 241944_x_at & $63(4-233)$ & 66 \\
\hline - BAFF & - TNFRSF13B/TACI & 207641_at & $266(50-745)$ & 95 \\
\hline \multirow[t]{2}{*}{ - APRIL } & - TNFRSF13C/Baff-R & NA & --- & --- \\
\hline & - TNFRSF17/BCMA & 206641_at & $3794(968-8301)$ & 100 \\
\hline \multirow[t]{4}{*}{ EGF family } & - ErbB1 & 211551_at & $56(6-148)$ & 64 \\
\hline & - ErbB2 & 216836_s_at & $30(2-106)$ & 5 \\
\hline & - ErbB3 & 202454_s_at & $47(79-172)$ & 59 \\
\hline & - ErbB4 & 214053_at & $51(2-1091)$ & 38 \\
\hline \multirow[t]{3}{*}{ VEGF family } & -VEGFR1/FLT1 & NA & --- & --- \\
\hline & -VEGFR2/FLK1 & NA & --- & --- \\
\hline & -VEGFR3/FLT4 & NA & --- & --- \\
\hline
\end{tabular}


Table 2: Affymetrix expression of growth factor receptor genes in MMC. (Continued)

\begin{tabular}{|c|c|c|c|c|}
\hline \multirow[t]{4}{*}{ FGF family } & - FGFR1 & NA & --- & --- \\
\hline & - FGFR2 & NA & --- & --- \\
\hline & - FGFR3 & 204379_s_at & $4.2(1-13160)$ & 10 \\
\hline & - FGFR4 & NA & --- & --- \\
\hline \multirow[t]{12}{*}{ Wnt family } & - Frizzled1 (Frz1) & 204451_at & $75(2-586)$ & 34 \\
\hline & - Frz2 & 210220_at & $30(1-680)$ & 30 \\
\hline & - Frz3 & 219683_at & $80(15-465)$ & 19 \\
\hline & - Frz4 & 218665_at & $84(2-348)$ & 92 \\
\hline & - Frz5 & NA & --- & 8 \\
\hline & - Frz6 & 203987_at & $229(6-1425)$ & \\
\hline & - Frz7 & 203706_s_at & $102(12-2228)$ & 98 \\
\hline & - Frz8 & 227405_s_at & $34(3-338)$ & 93 \\
\hline & - Frz9 & NA & --- & 15 \\
\hline & - Frz10 & NA & --- & --- \\
\hline & - LRP5 & NA & --- & -- \\
\hline & - LRP6 & 225745_at & $70(1-137)$ & 43 \\
\hline \multirow[t]{4}{*}{ Jagged } & - Notch1 & 218902_at & $85(24-233)$ & 47 \\
\hline & - Notch2 & 212377_s_at & $216(43-1743)$ & 100 \\
\hline & - Notch3 & 203238_s_at & $28(1.4-95)$ & 2 \\
\hline & - Notch4 & 205247_at & $40(8-190)$ & 35 \\
\hline
\end{tabular}

MGF receptor genes expressed in more than $90 \%$ of the MMC samples are indicated in bold. MGF receptor genes expressed in less than $5 \%$ of the MMC samples are indicated in grey. Probe sets noted "NA" were considered to be not informative (see additional file 1).

sion is increasing progressively throughout normal plasma cell differentiation. 4 MGF and $9 \mathrm{MGF}$ receptor genes were overexpressed in "PPC+BMPC" compared to $B$ cells. 11 MGF and 11 MGF receptor genes were overexpressed in BMPC compared to PPC. This suggests that $\mathrm{PC}$ differentiation, and in particular the transition from immature plasmablast to mature plasma cell, is associated with a stronger dependence on growth factors. In agreement with this finding, it has been shown that normal plasma cells can survive and produce antibodies for very long periods as soon as they are located in the appropriate survival niches in the BM [25]. In contrast, 3 MGF genes only (AREG, NRG3 and Wnt5A) and none of the MGF receptor genes were significantly overexpressed in $\mathrm{MMC}$ compared to BMPC. One explanation is that $M M C$ use the same growth factors than normal plasma cells. Accordingly, several growth factors for MMC also support the survival of normal plasma cells, like IL-6, BAFF and April [26,27], their specific receptors being expressed both in normal and malignant plasma cells (see table 2).
It was not in the scope of the study to validate the Affymetrix expression of all MGF. However, some of them have already been analysed by real-time RT-PCR and described by our group, like members of the EGFfamily. Using real-time RT-PCR on MMC from 7 patients and $\mathrm{U} 133 \mathrm{~A}+\mathrm{B}$ Affymetrix microarrays on a different cohort of $65 \mathrm{MM}$ patients' samples, we have shown that AREG [28], NRG2 and NRG3 [17] are significantly overexpressed in MMC compared to their normal counterpart. This is in agreement with the data presented here (see Figure S-I). Previously, we also compared the expression of EGF-family members in MMC ( $\mathrm{n}=7$ samples) and in the total BM microenvironment ( $\mathrm{n}=7$ samples), using real-time RT-PCR. We have shown that NRG2 and NRG3 are mainly expressed by MMC whereas HB-EGF is mainly expressed by the environment [17]. Again, those results correlate with the current Affymetrix data (see figure 2 for NRG2 and NRG3; and figure 4A for HBEGF). Other examples of formerly validated genes are Baff and April (Figures 4A and 3B), 2 members of the TNF superfamilly that were already shown to be highly 
expressed by the myeloma microenvironment compared to the MMC themselves by real-time RT-PCR [9]. Therefore, the good correlation between real-time RT-PCR analysis performed in independent series of samples and the Affymetrix expression profiles depicted here demonstrates the relevance of the present study and shows the power of microarrays to investigate as a whole the expression of MGF/MGFR genes in PC differentiation and MM.

Most interestingly, the microarrays analysis described in this paper uncovers new MGF and MGFR and/or describes for the fist time expression patterns of well known MGF. The new and most striking findings are discussed in the following.

IL-6 is an essential growth factor for myeloma cells $[4,5]$. Although it is now admitted that IL-6 is produced by the environment, it has been reported that IL- 6 is produced by MMC [4] and that autocrine IL- 6 production reflects a highly malignant phenotype [29]. Here we show that BMSC are the main producer of IL-6, in agreement with the literature data [30-32]. However, IL-6 can be produced by MMC in some patients (36\% presence, see additional file 2, table S-II), but at a much lower extend compared to BMSC (fold-chance in expression between BMSC and MMC = 33.4). An important issue would be to understand the significance of this low autocrine IL-6 expression, compared to the huge amounts produced by BMSC. We have shown that a weak autocrine IL-6 production is sufficient to trigger cell cycling on myeloma cell lines (HMCL), whereas survival of those cells requires large exogenous IL-6 concentrations [33]. It is noteworthy that immature CD $45^{+}$MMC express the IL-6 gene, unlike mature MMC [34]. In this population, autocrine IL-6 could be sufficient to trigger cell cycling, whereas the BM environment could be critical for triggering survival by producing other survival factors. In agreement with our previous findings [35], here we show that IL-6R and gp130 are expressed in 99\% and 100\% of the patients, respectively, indicating that the vast majority of the patients, if not all, is able to respond to IL-6 stimulation. We have recently shown that IL-6R expression in $\mathrm{MMC}$ is a bad prognostic factor due to its strong association with $\mathrm{t}(4: 14)$ translocation [35]. Interestingly, both IL6R and gp130 were overexpressed in normal plasma cells compared to B cells, in agreement with the known survival effect of IL-6 on plasma cells [26].

IGF-1 is an other essential growth factor for myeloma cells $[7,35,36]$ and inhibition of the IGF-1-pathway reduces myeloma cell growth both in vitro and in vivo [37-39]. It has been speculated that BMSC would be an important source of IGF-1 in MM, probably based on the fact that murine stromal cells do secrete IGF-1 [40]. However, we show here that MM-BMSC do not/weakly express IGF-1. IGF-1 expression was 92-fold higher in osteoclasts compared to BMSC (see Figures 3B) and 4/5
BMSC displayed an absent call for IGF-1 (additional file 2, table S-II). In addition, MMC from all 131 patients expressed IGF-1. The presence of autocrine IGF-1 has already been reported in some HMCL [7], but this is to our knowledge the first study showing IGF-1 expression as a hallmark of primary MMC. IGF-1R had $100 \%$ absent call in BMPC whereas it was expressed in $32 \%$ of the MMC samples (see table 2), suggesting that functional IGF-1/IGF-1R autocrine loops are present in MMC of those patients. Recently, we have shown that IGF-1R expression in MMC delineates a group with adverse prognosis [35].

HGF. Several evidences suggest that the HGF/c-Met signalling pathway plays an important role in the biology of MM [41-44]. Here we describe for the first time the expression of c-Met in a large cohort of patients, and we have found that it was expressed in MMC from 50\% of the patients. Although HGF expression in the environment (BMSC, CD14, PMN) was not statistically significantly different than that in MMC, it should be noted that HGF expression was very high in some patients' MMC (range 1-5318) suggesting that autocrine HGF loops are likely predominant in those high expresser patients. This is in agreement with elevated HGF levels found in the serum of some MM patients in association with advanced stages of MM and extended bone lesions [45,46]. It is noteworthy that HGF was overexpressed in MMC compared to BMPC in the public data set from the group of Shaughnessy ( $\mathrm{p} \leq .05$, fold-change $=7.5$, table S-VII). It did not reach the significance in our data set, probably because the number of samples is lesser.

Wnt-family. The expression of Wnt-family members and FRZ receptors has been documented in some myeloma cell lines [47] and in 4 primary MMC samples [48], and the biological relevance of this pathway in MM has been demonstrated $[48,49]$. In the present study, 8 Wnt were found in at least one BM subpopulation (MMC and/or environment): Wnt 3, 4,10A, 11, 16, 5A, 5B, 6. Noteworthy, Wnt5A was one of the 3 MGF significantly overexpressed in MMC compared to normal BMPC. All 7 FRZ receptors that could be interrogated with Affymetrix probe sets were expressed in some MMC samples and 3 of them (FRZ4, FRZ7, FRZ8) were expressed in more that $90 \%$ of the patients. LRP6, the required coreceptor of FRZ receptors, was expressed in $43 \%$ of the MMC samples. Altogether, those data indicate that Wnt/FRZ expression is a hallmark of MM. Dikkopf-1, an inhibitor of Wnt signaling expressed by primary MM cells, contributes to osteolytic bone disease by inhibiting the differentiation into osteoblasts [50]. Additional studies will be needed in order to understand the impact of DKK1 on the Wntinduced proliferation of myeloma cells. Furthermore, we show that expression of several Wnt and FRZ is upregulated during normal plasma cell differentiation. Wnt5A 
and Wnt10 as well as FRZ1,2,6,7,8 were overexpressed in BMPC compared to PPC. FRZ1,3,6 were overexpressed in (PPC+BMPC) compared to B cells. Those data provide a rationale to investigate the role of the Wnt/FRZ family in the biology of normal plasma cell.

FGF family. Analysis of the FGF/FGFR family in MM has been mainly restricted to the angiogenic factor FGF2 (also called basic-FGF) and the nature of the cells producing FGF2 has remained controversial [32,51]. Here show that BMSC are the main source of FGF2. FGF2 was also expressed in $29 \%$ of the patients' MMC (38/131 present call, median expression $=25$ ) in agreement with the data from Colla et al. [51], but the expression was 29.7-fold lower than that in BMSC. Other BM subpopulations (CD3, CD14, CD15) did not express FGF2 (see additional file 2, table S-II and figure $3 \mathrm{~A}$ ), as previously reported by Bisping et al. [32]. Furthermore, we show that other FGFfamily members are broadly expressed in MM. Among the 13/22 FGFs that could be investigated with Affymetrix probe sets, 10 were expressed in at least one BM subpopulation (MMC and/or environment), suggesting that, like FGF2, they may directly or indirectly stimulate MMC survival and proliferation. Of note, it has been shown that only FGF2, 8 and 13 could be detected at the protein level on $12 \mathrm{HMCL}$ whereas multiple FGFs were found at the mRNA level [52]. Although it was not in the scope of our study, FGF expression in MM should be validated at the protein level.

\section{Conclusion}

In conclusion, this study provides an extensive description of MGF gene expression in the various cell populations of the BM of patients with MM, including MMC and the environment, and during normal plasma cell differentiation. We show an overexpression of MGF and MGFR genes during plasma cell differentiation, in particular in BMPC compared to PPC. Additionally, this study points out that the majority of MGF is expressed by the tumor environment compared to MMC. Some MGF are expressed by the MMC themselves, with a strong heterogeneity among patients. This study provides new insights in the understanding of the intercellular communication signals in MM, which is of major interest in order to design efficient biologically-based treatments for MM.

\section{List of abbreviations used}

MM: multiple myeloma; MMC: myeloma cells; PPC: polyclonal plasmablasts; BMPC: bone marrow plasma cells; BM: bone marrow; BMSC: bone marrow stromal cells; PMN: polymorphonuclear neutrophils; MGF: myeloma growth factor; MGFR: myeloma growth factor receptor.

\section{Additional material}

Additional file 1 Gene expression profiling analysis. Material and methods describing how the so-called "non informative" probe sets were defined in the study.

Additional file 2 Expression of MGF genes in bone marrow cell populations and during normal plasma cell differentiation. The file includes 7 tables showing the median expression and fold change in expression of MGF genes. Table S-I. Myeloma MGF genes. Table S-II. Myeloma niche MGF genes. Table S-III. Environment MGF genes. Table S-IV. Genes not statistically significantly overexpressed in cell populations. Table S-V. Expression of MGF during normal plasma cell differe. Table S-VI. Expression of MGF receptors during normal plasma cell differentiation and in MMC. Table S-VII. Expression of MGF and MGF receptors in BMPC and MMC samples from a public data set.

Additional file 3 Expression of MGF and MGF receptor genes during normal plasma cell differentiation and in MMC. The file includes 2 figures that summarize the MGF (Figure S-I) and MGF receptor (Figure S-II) gene expression during normal plasma cell differentiation and in MMC.

\section{Competing interests}

The authors declare that they have no competing interests.

\section{Authors' contributions}

KM designed research, performed the experiments, analyzed data and wrote the paper. DH, TM, JFR and HG collected bone marrow samples and clinical data. JM, DH, TR, MJ and STP analyzed data. BK is the senior investigator who designed research and wrote the paper. All authors read and approved the final manuscript.

\section{Acknowledgements}

This work was supported by grants from the Ligue Nationale Contre le Cancer (équipe labellisée, 2009), Paris, France, from INCA ( ${ }^{\circ}$ R07001FN) and from BMSCNET European strep (NE06005FF), the Hopp-Foundation, Germany, the University of Heidelberg, Germany, the National Centre for Tumor Diseases, Heidelberg, Germany, the Tumorzentrum Heidelberg/Mannheim, Germany

\section{Author Details}

1INSERM, U847, Montpellier, F-34197 France, 2CHU Montpellier, Institute of Research in Biotherapy, F-34285 Montpellier, France, ${ }^{3}$ Medizinische Klinik V, Universitätsklinikum Heidelberg, INF410, D-69120 Heidelberg, Germany, 4Nationales Centrum für Tumorerkrankungen, INF350, D-69120 Heidelberg, Germany, 5 Université MONTPELLIER1, UFR Médecine, Montpellier, France and ${ }^{6}$ Academic Medical Center, Department of Pathology, 1105 AZ Amsterdam, The Netherlands

Received: 6 November 2009 Accepted: 13 May 2010

Published: 13 May 2010

\section{References}

1. Attal M, Harousseau JL, Facon T, Guilhot F, Doyen C, Fuzibet JG, Monconduit M, Hulin C, Caillot D, Bouabdallah R, Voillat L, Sotto JJ, Grosbois B, Bataille R: Single versus double autologous stem-cell transplantation for multiple myeloma. N Engl J Med 2003, 349(26):2495-2502.

2. Higgins MJ, Fonseca R: Genetics of multiple myeloma. Best Pract Res Clin Haematol 2005, 18(4):525-536.

3. Klein B, Tarte K, Jourdan M, Mathouk K, Moreaux J, Jourdan E, Legouffe E, De Vos J, Rossi JF: Survival and proliferation factors of normal and malignant plasma cells. Int J Hemato/ 2003, 78(2):106-113.

4. Kawano M, Hirano T, Matsuda T, Taga T, Horii Y, Iwato K, Asaoka H, Tang B, Tanabe O, Tanaka H, Kuramoto A, Kishimoto T: Autocrine generation and essential requirement of BSF-2/IL-6 for human multiple myeloma. 1988, 332:83-85.

5. Klein B, Zhang XG, Jourdan M, Content J, Houssiau F, Aarden L, Piechaczyk $\mathrm{M}$, Bataille R: Paracrine rather than autocrine regulation of myelomacell growth and differentiation by interleukin-6. Blood 1989, 73(2):517-526. 
6. Zhang XG, Bataille R, Widjenes J, Klein B: Interleukin-6 dependence of advanced malignant plasma cell dyscrasias. 1992, 69(6):1373-1376.

7. Georgii-Hemming P, Wiklund HJ, Ljunggren O, Nilsson K: Insulin-like growth factor $\mathrm{I}$ is a growth and survival factor in human multiple myeloma cell lines. Blood 1996, 88:2250-2258.

8. De Vos J, Hose D, Reme T, Tarte K, Moreaux J, Mahtouk K, Jourdan M, Goldschmidt H, Rossi JF, Cremer FW, Klein B: Microarray-based understanding of normal and malignant plasma cells. Immuno/ Rev 2006, 210:86-104.

9. Moreaux J, Cremer FW, Reme T, Raab M, Mahtouk K, Kaukel P, Pantesco V, De Vos J, Jourdan E, Jauch A, Legouffe E, Moos M, Fiol G, Goldschmidt H, Rossi JF, Hose D, Klein B: The level of TACl gene expression in myeloma cells is associated with a signature of microenvironment dependence versus a plasmablastic signature. Blood 2005, 106(3):1021-1030.

10. Tarte K, De Vos J, Thykjaer T, Zhan F, Fiol G, Costes V, Reme T, Legouffe E, Rossi JF, Shaughnessy J Jr, Orntoft TF, Klein B: Generation of polyclonal plasmablasts from peripheral blood $B$ cells: a normal counterpart of malignant plasmablasts. Blood 2002, 100(4):1113-1122.

11. Jourdan M, Caraux A, De Vos J, Fiol G, Larroque M, Cognot C, Bret C, Duperray C, Hose D, Klein B: An in vitro model of differentiation of memory $B$ cells into plasmablasts and plasma cells including detailed phenotypic and molecular characterization. Blood 2009, 114(25):5173-5181.

12. Reme T, Hose D, De Vos J, Vassal A, Poulain PO, Pantesco V, Goldschmidt $H$, Klein B: A new method for class prediction based on signed-rank algorithms applied to Affymetrix microarray experiments. $B M C$ Bioinformatics 2008, 9:16.

13. Assou S, Lecarrour T, Tondeur S, Strom S, Gabelle A, Marty S, Nadal L, Pantesco V, Reme T, Hugnot JP, Gasca S, Hovatta O, Hamamah S, Klein B, De Vos J: A meta-analysis of human embryonic stem cells transcriptome integrated into a web-based expression atlas. Stem Cells 2007.

14. Zhan F, Huang Y, Colla S, Stewart JP, Hanamura I, Gupta S, Epstein J, Yaccoby S, Sawyer J, Burington B, Anaissie E, Hollmig K, Pineda-Roman M, Tricot G, van Rhee F, Walker R, Zangari M, Crowley J, Barlogie B, Shaughnessy JD Jr: The molecular classification of multiple myeloma. Blood 2006, 108(6):2020-2028.

15. Zhan F, Barlogie B, Arzoumanian V, Huang Y, Williams DR, Hollmig K, Pineda-Roman M, Tricot G, van Rhee F, Zangari M, Dhodapkar M, Shaughnessy JD Jr: Gene-expression signature of benign monoclonal gammopathy evident in multiple myeloma is linked to good prognosis. Blood 2007, 109(4):1692-1700.

16. Mahtouk K, Hose D, De Vos J, Moreaux J, Jourdan M, Rossi JF, Reme T, Goldschmidt H, Klein B: Input of DNA microarrays to identify novel mechanisms in multiple myeloma biology and therapeutic applications. Clin Cancer Res 2007, 13(24):7289-7295

17. Mahtouk K, Cremer FW, Reme T, Jourdan M, Baudard M, Moreaux J, Requirand G, Fiol G, De Vos J, Moos M, Quittet P, Goldschmidt H, Rossi JF, Hose D, Klein B: Heparan sulphate proteoglycans are essential for the myeloma cell growth activity of EGF-family ligands in multiple myeloma. Oncogene 2006, 25(54):7180-7191.

18. Costes V, Portier M, Lu ZY, Rossi JF, Bataille R, Klein B: Interleukin-1 in multiple myeloma: producer cells and their role in the control of IL-6 production. BrJ Haematol 1998, 103(4):1152-1160

19. Gu ZJ, De Vos J, Rebouissou C, Jourdan M, Zhang XG, Rossi JF, Wijdenes J, Klein B: Agonist anti-gp130 transducer monoclonal antibodies are human myeloma cell survival and growth factors. Leukemia 2000, 14(1):188-197.

20. Tokoyoda K, Egawa T, Sugiyama T, Choi BI, Nagasawa T: Cellular niches controlling $\mathrm{B}$ lymphocyte behavior within bone marrow during development. Immunity 2004, 20(6):707-718.

21. Chatterjee M, Stuhmer T, Herrmann P, Bommert K, Dorken B, Bargou RC: Combined disruption of both the MEK/ERK and the IL-6R/STAT3 pathways is required to induce apoptosis of multiple myeloma cells in the presence of bone marrow stromal cells. Blood 2004, 104(12):3712-3721

22. Yaccoby S, Pearse RN, Johnson CL, Barlogie B, Choi Y, Epstein J: Myeloma interacts with the bone marrow microenvironment to induce osteoclastogenesis and is dependent on osteoclast activity. $\mathrm{Br} J$ Haematol 2002, 116(2):278-290.
23. Cao W, Liu YJ: Innate immune functions of plasmacytoid dendritic cells. Curr Opin Immunol 2007, 19(1):24-30.

24. Corre J, Mahtouk K, Attal M, Gadelorge M, Huynh A, Fleury-Cappellesso S, Danho C, Laharrague P, Klein B, Reme T, Bourin P: Bone marrow mesenchymal stem cells are abnormal in multiple myeloma. Leukemia 2007, 21(5):1079-1088.

25. Radbruch A, Muehlinghaus G, Luger EO, Inamine A, Smith KG, Dorner T, Hiepe F: Competence and competition: the challenge of becoming a long-lived plasma cell. Nat Rev Immunol 2006, 6(10):741-750.

26. Cassese G, Arce S, Hauser AE, Lehnert K, Moewes B, Mostarac M, Muehlinghaus G, Szyska M, Radbruch A, Manz RA: Plasma cell survival is mediated by synergistic effects of cytokines and adhesion-dependent signals. JImmuno/ 2003, 171(4):1684-1690.

27. O'Connor BP, Raman VS, Erickson LD, Cook WJ, Weaver LK, Ahonen C, Lin $L L$, Mantchev GT, Bram RJ, Noelle RJ: BCMA is essential for the survival of long-lived bone marrow plasma cells. J Exp Med 2004, 199(1):91-98.

28. Mahtouk K, Hose D, Reme T, De Vos J, Jourdan M, Moreaux J, Fiol G, Raab M, Jourdan E, Grau V, Moos M, Goldschmidt H, Baudard M, Rossi JF, Cremer FW, Klein B: Expression of EGF-family receptors and amphiregulin in multiple myeloma. Amphiregulin is a growth factor for myeloma cells. Oncogene 2005, 24(21):3512-3524.

29. Frassanito MA, Cusmai A, lodice G, Dammacco F: Autocrine interleukin-6 production and highly malignant multiple myeloma: relation with resistance to drug-induced apoptosis. Blood 2001, 97(2):483-489.

30. Uchiyama H, Barut BA, Mohrbacher AF, Chauhan D, Anderson KC: Adhesion of human myeloma-derived cell lines to bone marrow stromal cells stimulates interleukin-6 secretion. Blood 1993, 82(12):3712-3720.

31. Dankbar B, Padro T, Leo R, Feldmann B, Kropff M, Mesters RM, Serve H, Berdel WE, Kienast J: Vascular endothelial growth factor and interleukin6 in paracrine tumor-stromal cell interactions in multiple myeloma. Blood 2000, 95(8):2630-2636

32. Bisping G, Leo R, Wenning D, Dankbar B, Padro T, Kropff M, Scheffold C, Kroger M, Mesters RM, Berdel WE, Kienast J: Paracrine interactions of basic fibroblast growth factor and interleukin-6 in multiple myeloma. Blood 2003, 101(7):2775-2783.

33. Jourdan M, Mahtouk K, Veyrune JL, Couderc G, Fiol G, Redal N, Duperray C, De Vos J, Klein B: Delineation of the roles of paracrine and autocrine interleukin-6 (IL-6) in myeloma cell lines in survival versus cell cycle. A possible model for the cooperation of myeloma cell growth factors. Eur Cytokine Netw 2005, 16(1):57-64.

34. Hata H, Xiao H, Petrucci MT, Woodliff J, Chang R, Epstein J: Interleukin-6 gene expression in multiple myeloma: a characteristic of immature tumor cells. 1993, 81:3357-3364.

35. Sprynski AC, Hose D, Caillot L, Reme T, Shaughnessy JD Jr, Barlogie B, Seckinger A, Moreaux J, Hundemer M, Jourdan M, Meissner T, Jauch A, Mahtouk K, Kassambara A, Bertsch U, Rossi JF, Goldschmidt H, Klein B: The role of IGF-1 as a major growth factor for myeloma cell lines and the prognostic relevance of the expression of its receptor. Blood 2009.

36. Ferlin M, Noraz N, Hertogh C, Brochier J, Taylor N, Klein B: Insulin-like growth factor induces the survival and proliferation of myeloma cells through an IL-6-independent transduction pathway. Br J Haematol 2000, 111(2):626-634.

37. Menu E, Jernberg Wiklund H, Stromberg T, De Raeve H, Girnita L, Larsson $\mathrm{O}$, Axelson M, Asosingh K, Nilsson K, Van Camp B, Vanderkerken K: Inhibiting the IGF-1 receptor tyrosine kinase with the cyclolignan PPP: an in vitro and in vivo study in the 5T33 MM mouse model. Blood 2005.

38. Stromberg T, Ekman S, Girnita L, Dimberg LY, Larsson O, Axelson M, Lennartsson J, Hellman U, Carlson K, Osterborg A, Vanderkerken K, Nilsson $\mathrm{K}$, Jernberg-Wiklund H: IGF-1 receptor tyrosine kinase inhibition by the cyclolignan PPP induces G2/M-phase accumulation and apoptosis in multiple myeloma cells. Blood 2006, 107(2):669-678.

39. Descamps G, Wuilleme-Toumi S, Trichet V, Venot C, Debussche L, Hercend $\mathrm{T}$, Collette M, Robillard N, Bataille R, Amiot M: CD45neg but not CD45pos human myeloma cells are sensitive to the inhibition of IGF-1 signaling by a murine anti-IGF-1R monoclonal antibody, mAVE1642. J Immunol 2006, 177(6):4218-4223.

40. Abboud SL, Bethel CR, Aron DC: Secretion of insulinlike growth factor I and insulinlike growth factor-binding proteins by murine bone marrow stromal cells. J Clin Invest 1991, 88(2):470-475. 
41. Borset M, Hjorth-Hansen H, Seidel C, Sundan A, Waage A: Hepatocyte growth factor and its receptor c-met in multiple myeloma. 1996, 88:3998-4004

42. Derksen PW, Keehnen RM, Evers LM, van Oers MH, Spaargaren M, Pals ST: Cell surface proteoglycan syndecan-1 mediates hepatocyte growth factor binding and promotes Met signaling in multiple myeloma. Blood 2002, 99(4):1405-1410

43. Hov H, Holt RU, Ro TB, Fagerli UM, Hjorth-Hansen H, Baykov V, Christensen JG, Waage A, Sundan A, Borset M: A selective c-met inhibitor blocks an autocrine hepatocyte growth factor growth loop in ANBL-6 cells and prevents migration and adhesion of myeloma cells. Clin Cancer Res 2004, 10(19):6686-6694.

44. Du W, Hattori Y, Yamada T, Matsumoto K, Nakamura T, Sagawa M, Otsuki T, Niikura T, Nukiwa T, Ikeda Y: NK4, an antagonist of hepatocyte growth factor (HGF), inhibits growth of multiple myeloma cells: molecular targeting of angiogenic growth factor. Blood 2007, 109(7):3042-3049.

45. Seidel C, Borset M, Turesson I, Abildgaard N, Sundan A, Waage A: Elevated serum concentrations of hepatocyte growth factor in patients with multiple myeloma. The Nordic Myeloma Study Group. Blood 1998, 91(3):806-812.

46. Alexandrakis MG, Passam FH, Sfiridaki A, Kandidaki E, Roussou P, Kyriakou DS: Elevated serum concentration of hepatocyte growth factor in patients with multiple myeloma: correlation with markers of disease activity. Am J Hematol 2003, 72(4):229-233.

47. Qiang YW, Endo Y, Rubin JS, Rudikoff S: Wnt signaling in B-cell neoplasia. Oncogene 2003, 22(10):1536-1545

48. Derksen PW, Tjin E, Meijer HP, Klok MD, MacGillavry HD, van Oers MH, Lokhorst HM, Bloem AC, Clevers H, Nusse R, Neut R van der, Spaargaren M, Pals ST: Illegitimate WNT signaling promotes proliferation of multiple myeloma cells. Proc Natl Acad Sci USA 2004, 101(16):6122-6127.

49. Qiang YW, Walsh K, Yao L, Kedei N, Blumberg PM, Rubin JS, Shaughnessy J $\mathrm{Jr}$, Rudikoff S: Wnts induce migration and invasion of myeloma plasma cells. Blood 2005, 106(5):1786-1793.

50. Tian E, Zhan F, Walker R, Rasmussen E, Ma Y, Barlogie B, Shaughnessy JD Jr: The role of the Wnt-signaling antagonist DKK1 in the development of osteolytic lesions in multiple myeloma. N Engl J Med 2003, 349(26):2483-2494.

51. Colla S, Morandi F, Lazzaretti M, Polistena P, Svaldi M, Coser P, Bonomini S, Hojden M, Martella E, Chisesi T, Rizzoli V, Giuliani N: Do human myeloma cells directly produce basic FGF? Blood 2003, 102(8):3071-3072. author reply 3072-3073

52. Krejci P, Mekikian PB, Wilcox WR: The fibroblast growth factors in multiple myeloma. Leukemia 2006, 20(6):1165-1168.

53. Lentzsch S, Gries M, Janz M, Bargou R, Dorken B, Mapara MY: Macrophage inflammatory protein 1-alpha (MIP-1 alpha) triggers migration and signaling cascades mediating survival and proliferation in multiple myeloma (MM) cells. Blood 2003, 101(9):3568-3573.

54. Choi SJ, Oba Y, Gazitt Y, Alsina M, Cruz J, Anderson J, Roodman GD: Antisense inhibition of macrophage inflammatory protein 1-alpha blocks bone destruction in a model of myeloma bone disease. J Clin Invest 2001, 108(12):1833-1841.

55. Oyajobi BO, Franchin G, Williams PJ, Pulkrabek D, Gupta A, Munoz S, Grubbs B, Zhao M, Chen D, Sherry B, Mundy GR: Dual effects of macrophage inflammatory protein-1alpha on osteolysis and tumor burden in the murine 5TGM1 model of myeloma bone disease. Blood 2003, 102(1):311-319.

56. Vallet S, Raje N, Ishitsuka K, Hideshima T, Podar K, Chhetri S, Pozzi S, Breitkreutz I, Kiziltepe T, Yasui H, Ocio EM, Shiraishi N, Jin J, Okawa Y, Ikeda H, Mukherjee S, Vaghela N, Cirstea D, Ladetto M, Boccadoro M, Anderson KC: MLN3897, a novel CCR1 inhibitor, impairs osteoclastogenesis and inhibits the interaction of multiple myeloma cells and osteoclasts. Blood 2007, 110(10):3744-3752.

57. Yeh HS, Chen H, Manyak SJ, Swift RA, Campbell RA, Wang C, Li M, Lee HJ, Waterman G, Gordon MS, Ma J, Bonavida B, Berenson JR: Serum pleiotrophin levels are elevated in multiple myeloma patients and correlate with disease status. Br J Haematol 2006, 133(5):526-529.

58. Chen H, Gordon MS, Campbell RA, Li M, Wang CS, Lee HJ, Sanchez E, Manyak SJ, Gui D, Shalitin D, Said J, Chang Y, Deuel TF, Baritaki S, Bonavida $\mathrm{B}$, Berenson JR: Pleiotrophin is highly expressed by myeloma cells and promotes myeloma tumor growth. Blood 2007, 110(1):287-295.
59. Pearse RN, Swendeman SL, Li Y, Rafii D, Hempstead BL: A neurotrophin axis in myeloma: TrkB and BDNF promote tumor-cell survival. Blood 2005, 105(11):4429-4436.

60. Zhang XG, Gaillard JP, Robillard N, Lu ZY, Gu ZJ, Jourdan M, Boiron JM, Bataille R, Klein B: Reproducible obtaining of human myeloma cell lines as a model for tumor stem cell study in human multiple myeloma. Blood 1994, 83(12):3654-3663.

61. Jourdan M, De Vos J, Mechti N, Klein B: Regulation of Bcl-2-family proteins in myeloma cells by three myeloma survival factors: interleukin-6, interferon-alpha and insulin-like growth factor 1. Cell Death Differ 2000, 7(12):1244-1252

62. Bataille $R$, Jourdan M, Zhang XG, Klein B: Serum levels of interleukin 6, a potent myeloma cell growth factor, as a reflect of disease severity in plasma cell dyscrasias. JClin/nvest 1989, 84(6):2008-2011.

63. Gaillard JP, Bataille R, Brailly H, Zuber C, Yasukawa K, Attal M, Maruo N, Taga T, Kishimoto T, Klein B: Increased and highly stable levels of functional soluble interleukin-6 receptor in sera of patients with monoclonal gammopathy. Eur J Immunol 1993, 23(4):820-824.

64. Ludwig H, Nachbaur DM, Fritz E, Krainer M, Huber H: Interleukin-6 is a prognostic factor in multiple myeloma. 1991, 77:2794-2795.

65. Klein B, Wijdenes J, Zhang XG, Jourdan M, Boiron JM, Brochier J, Liautard J, Merlin M, Clement C, Morel-Fournier B: Murine anti-interleukin-6 monoclonal antibody therapy for a patient with plasma cell leukemia. Blood 1991, 78(5):1198-1204

66. Bataille R, Barlogie B, Lu ZY, Rossi JF, Lavabre-Bertrand T, Beck T, Wijdenes $J$, Brochier J, Klein B: Biologic effects of anti-interleukin-6 murine monoclonal antibody in advanced multiple myeloma. Blood 1995, 86(2):685-691

67. Rossi JF, Fegueux N, Lu ZY, Legouffe E, Exbrayat C, Bozonnat MC, Navarro R, Lopez E, Quittet P, Daures JP, Rouille V, Kanouni T, Widjenes J, Klein B: Optimizing the use of anti-interleukin- 6 monoclonal antibody with dexamethasone and $140 \mathrm{mg} / \mathrm{m} 2$ of melphalan in multiple myeloma: results of a pilot study including biological aspects. Bone Marrow Transplant 2005, 36(9):771-779.

68. Voorhees PM, Chen Q, Kuhn DJ, Small GW, Hunsucker SA, Strader JS, Corringham RE, Zaki MH, Nemeth JA, Orlowski RZ: Inhibition of Interleukin-6 Signaling with CNTO 328 Enhances the Activity of Bortezomib in Preclinical Models of Multiple Myeloma. Clin Cancer Res 2007, 13(21):6469-6478

69. Gu ZJ, Wijdenes J, Zhang XG, Hallet MM, Clement C, Klein B: Anti-gp130 transducer monoclonal antibodies specifically inhibiting ciliary neurotrophic factor, interleukin-6, interleukin-11, leukemia inhibitory factor or oncostatin M. 1996, 190(1):21-27.

70. Burger R, Bakker F, Guenther A, Baum W, Schmidt-Arras D, Hideshima T, Tai YT, Shringarpure R, Catley L, Senaldi G, Gramatzki M, Anderson KC: Functional significance of novel neurotrophin-1/B cell-stimulating factor-3 (cardiotrophin-like cytokine) for human myeloma cell growth and survival. Br J Haematol 2003, 123(5):869-878.

71. Lu ZY, Zhang XG, Rodriguez C, Wijdenes J, Gu ZJ, Morel-Fournier B, Harousseau JL, Bataille R, Rossi JF, Klein B: Interleukin-10 is a proliferation factor but not a differentiation factor for human myeloma cells. Blood 1995, 85(9):2521-2527.

72. Gu ZJ, Costes V, Lu ZY, Zhang XG, Pitard V, Moreau JF, Bataille R, Wijdenes J, Rossi JF, Klein B: Interleukin-10 is a growth factor for human myeloma cells by induction of an oncostatin M autocrine loop. Blood 1996, 88(10):3972-3986.

73. Tinhofer I, Marschitz I, Henn T, Egle A, Greil R: Expression of functional interleukin-15 receptor and autocrine production of interleukin-15 as mechanisms of tumor propagation in multiple myeloma. Blood 2000, 95(2):610-618.

74. Brenne AT, Baade Ro T, Waage A, Sundan A, Borset M, Hjorth-Hansen H: Interleukin-21 is a growth and survival factor for human myeloma cells. Blood 2002, 99(10):3756-3762.

75. Jourdan M, Tarte K, Legouffe E, Brochier J, Rossi JF, Klein B: Tumor necrosis factor is a survival and proliferation factor for human myeloma cells. Eur Cytokine Netw 1999, 10(1):65-70.

76. Hideshima T, Chauhan D, Schlossman R, Richardson P, Anderson KC: The role of tumor necrosis factor alpha in the pathophysiology of human multiple myeloma: therapeutic applications. Oncogene 2001, 20(33):4519-4527. 
77. Carter A, Merchav S, Silvian-Draxler I, Tatarsky I: The role of interleukin-1 and tumour necrosis factor-alpha in human multiple myeloma. $\mathrm{Br} J$ Haematol 1990, 74(4):424-431.

78. Borset M, Waage A, Brekke OL, Helseth E: TNF and IL-6 are potent growth factors for $\mathrm{OH}-2$, a novel human myeloma cell line. Eur J Haematol 1994, 53(1):31-37.

79. Moreaux J, Legouffe E, Jourdan E, Quittet P, Reme T, Lugagne C, Moine P, Rossi JF, Klein B, Tarte K: BAFF and APRIL protect myeloma cells from apoptosis induced by interleukin 6 deprivation and dexamethasone. Blood 2004, 103(8):3148-3157.

80. Novak AJ, Darce JR, Arendt BK, Harder B, Henderson K, Kindsvogel W, Gross JA, Greipp PR, Jelinek DF: Expression of BCMA, TACI, and BAFF-R in multiple myeloma: a mechanism for growth and survival. Blood 2004, 103(2):689-694

81. Abe M, Kido S, Hiasa M, Nakano A, Oda A, Amou H, Matsumoto T: BAFF and APRIL as osteoclast-derived survival factors for myeloma cells: a rationale for $\mathrm{TACl}-\mathrm{FC}$ treatment in patients with multiple myeloma. Leukemia 2006, 20(7):1313-1315.

82. Yaccoby S, Pennisi A, Li X, Dillon SR, Zhan F, Barlogie B, Shaughnessy JD Jr: Atacicept (TACl-lg) inhibits growth of $\mathrm{TACl}($ high) primary myeloma cells in SCID-hu mice and in coculture with osteoclasts. Leukemia 2007.

83. Wang YD, De Vos J, Jourdan M, Couderc G, Lu ZY, Rossi JF, Klein B: Cooperation between heparin-binding EGF-like growth factor and interleukin- 6 in promoting the growth of human myeloma cells. Oncogene 2002, 21(16):2584-2592.

84. Mahtouk K, Jourdan M, De Vos J, Hertogh C, Fiol G, Jourdan E, Rossi JF, Klein B: An inhibitor of the EGF receptor family blocks myeloma cell growth factor activity of HB-EGF and potentiates dexamethasone or anti-IL-6 antibody-induced apoptosis. Blood 2004, 103(5):1829-1837.

85. Jundt F, Probsting KS, Anagnostopoulos I, Muehlinghaus G, Chatterjee M, Mathas S, Bargou RC, Manz R, Stein H, Dorken B: Jagged1-induced Notch signaling drives proliferation of multiple myeloma cells. Blood 2004, 103(9):3511-3515.

86. Houde C, Li Y, Song L, Barton K, Zhang Q, Godwin J, Nand S, Toor A, Alkan S, Smadja NV, Avet-Loiseau H, Lima CS, Miele L, Coignet LJ:

Overexpression of the NOTCH ligand JAG2 in malignant plasma cells from multiple myeloma patients and cell lines. Blood 2004, 104(12):3697-3704

87. Nefedova Y, Cheng P, Alsina M, Dalton WS, Gabrilovich DI: Involvement of Notch-1 signaling in bone marrow stroma-mediated de novo drug resistance of myeloma and other malignant lymphoid cell lines. Blood 2004, 103(9):3503-3510.

88. Nefedova Y, Sullivan DM, Bolick SC, Dalton WS, Gabrilovich DI: Inhibition of Notch signaling induces apoptosis of myeloma cells and enhances sensitivity to chemotherapy. Blood 2007

89. Podar K, Tai YT, Davies FE, Lentzsch S, Sattler M, Hideshima T, Lin BK, Gupta D, Shima Y, Chauhan D, Mitsiades C, Raje N, Richardson P, Anderson KC: Vascular endothelial growth factor triggers signaling cascades mediating multiple myeloma cell growth and migration. Blood 2001, 98(2):428-435.

90. Kumar S, Witzig TE, Timm M, Haug J, Wellik L, Fonseca R, Greipp PR, Rajkumar SV: Expression of VEGF and its receptors by myeloma cells. Leukemia 2003, 17(10):2025-2031.

91. Le Gouill S, Podar K, Amiot M, Hideshima T, Chauhan D, Ishitsuka K, Kumar S, Raje N, Richardson PG, Harousseau JL, Anderson KC: VEGF induces Mcl1 up-regulation and protects multiple myeloma cells against apoptosis. Blood 2004, 104(9):2886-2892.

92. Podar K, Tonon G, Sattler M, Tai YT, Legouill S, Yasui H, Ishitsuka K, Kumar S, Kumar R, Pandite LN, Hideshima T, Chauhan D, Anderson KC: The smallmolecule VEGF receptor inhibitor pazopanib (GW786034B) targets both tumor and endothelial cells in multiple myeloma. Proc Natl Acad Sci USA 2006, 103(51):19478-19483.

\section{Pre-publication history}

The pre-publication history for this paper can be accessed here: http://www.biomedcentral.com/1471-2407/10/198/prepub

doi: $10.1186 / 1471-2407-10-198$

Cite this article as: Mahtouk et al., Growth factors in multiple myeloma: a comprehensive analysis of their expression in tumor cells and bone marrow environment using Affymetrix microarrays BMC Cancer 2010, 10:198

\section{Submit your next manuscript to BioMed Centra and take full advantage of:}

- Convenient online submission

- Thorough peer review

- No space constraints or color figure charges

- Immediate publication on acceptance

- Inclusion in PubMed, CAS, Scopus and Google Scholar

- Research which is freely available for redistribution

Submit your manuscript at www.biomedcentral.com/submit
C Biomed Central 